\title{
A Preliminary Study of the United Nations Sustainable Development Goals in Canadian Industrial and Graphic Design School Curricula
}

By

Jed Looker

A thesis submitted to the Faculty of Graduate and Postdoctoral Affairs in partial fulfillment of the requirements for the degree of

Master of Design

in

Industrial Design

Carleton University

Ottawa, Ontario

(C) 2017 Jed Looker 


\begin{abstract}
This preliminary study explores to what extent three- and four-year Canadian industrial and graphic design programs have included the United Nations (UN) Sustainable Development Goals (SDGs) in their curricula. Research was divided into two parts. The first was a review of online program descriptions, and the second a semi-structured interview of program coordinators. Findings show the SDGs are relatively unknown to Canadian industrial and graphic design programs, their institution, and professional community. However, coordinators discussed the role of design in overcoming sustainable development (SD) challenges, and our findings show most programs have already worked SD concepts into their curricula. Furthermore, student reaction to learning about SD was positive. What coordinators questioned was how the SDGs related to applied learning and aligned with faculty research. This study concludes proposing future research into the SDGs in relation to design school curricula and faculty research.
\end{abstract}

Keywords: Sustainable Development Goals; sustainable development; design curricula; professional design associations; Canadian context 


\section{Acknowledgments}

To Mom and Dad, who taught me how to dream big and

work hard. These two skills are invaluable.

To my partner, Mike Kent, for his love and support in all my ambitions.

To my thesis supervisors, Dr. Thomas Garvey and Dr. Stephen Fai, for

being one step ahead and nudging me towards discovery.

To the professors and staff of the School of Industrial Design who

have all, at one time or another, helped me with my studies.

To my colleagues at Algonquin College. It would not have been possible to both teach and study without your support.

To my good friends, who have been cheering me on from the sidelines, and editing my drafts for free.

And to my grandfather, Fred G. Looker, who immigrated to Canada to provide his family access to higher education. This is for you. 


\section{Table of Contents}

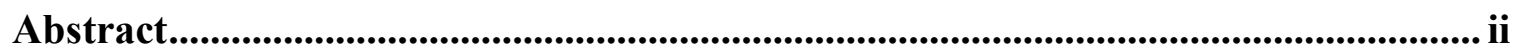

Acknowledgments ................................................................................................................................ iii

Table of Contents ........................................................................................................... iv

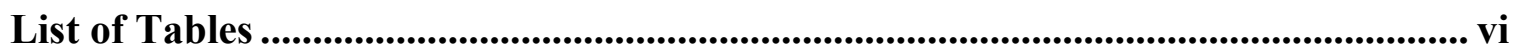

List of Figures....................................................................................................................................... viii

List of Appendices.......................................................................................................................... viii

List of Abbreviations ............................................................................................. ix

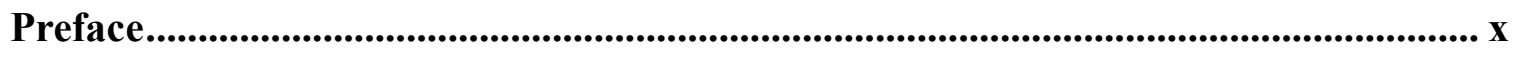

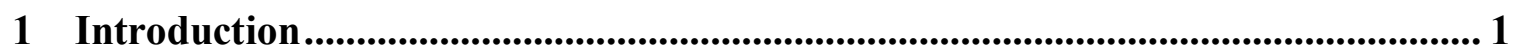

$1.1 \quad$ Background and Scope ………………………………………………………...

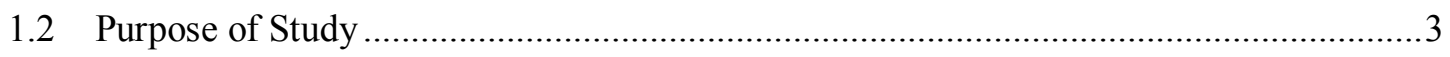

1.3 Research Question ..............................................................................................

1.4 Contributions to the Field ..................................................................................

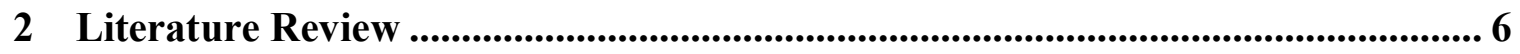

2.1 The Pillars of Sustainability ………………………………………………………..6

$2.2 \quad$ Higher Education and Sustainable Development ………………………………….......

2.3 Higher Education and Sustainable Development Goals .................................................9

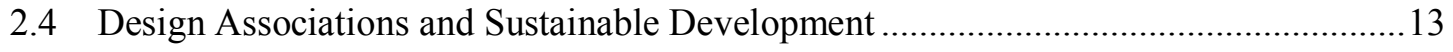

3 Methods.......................................................................................................................... 16

$4 \quad$ Findings................................................................................................................................ 19

4.1 Sample

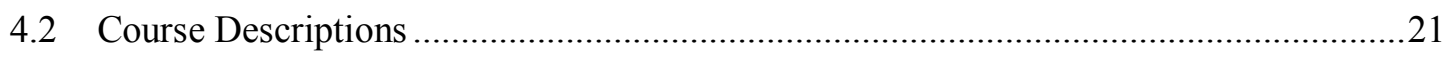

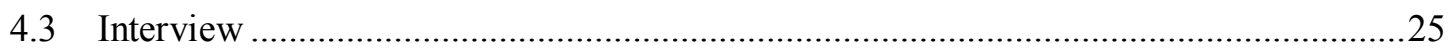

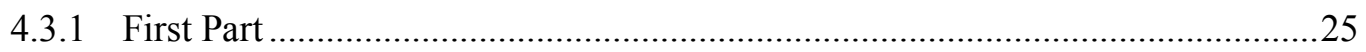




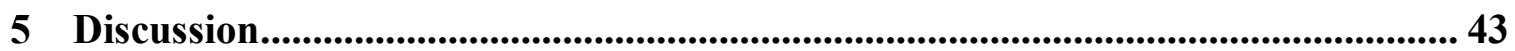

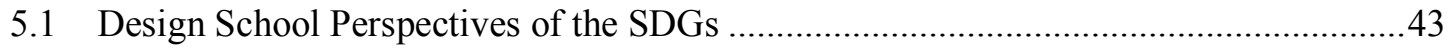

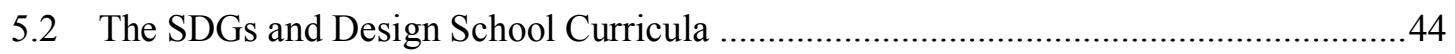

5.3 University and College Strategy and the SDGs ........................................................46

5.4 SDGs and the Professional Design Community …..................................................4

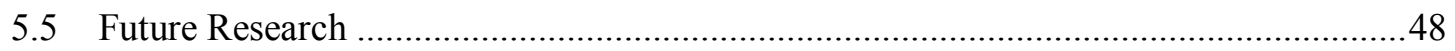

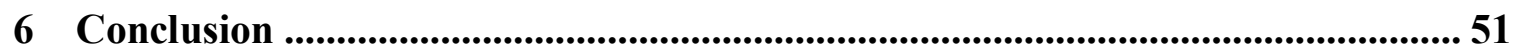

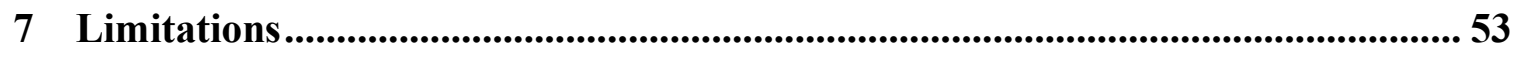

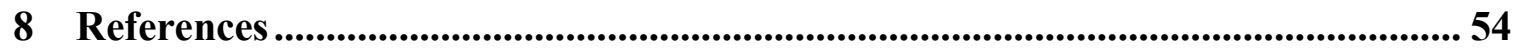

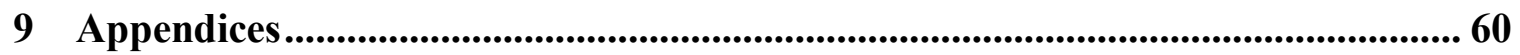




\section{List of Tables}

Table 1. Sample of Design Programs by Accreditation ............................................... 19

Table 2. Sample of Design Programs by Province ...................................................... 19

Table 3. Interview Participants by Accreditation ........................................................ 21

Table 4. Interview Participants by Province................................................................ 21

Table 5. Exact Keyword Search of Design Program Descriptions ............................... 21

Table 6. Thematic Categories Identified in Program Descriptions .............................. 22

Table 7. Themes Identified in the Program Category ................................................ 23

Table 8. Themes Identified in the Profession Category ……………………………... 24

Table 9. SD Sub-Themes Identified in the Program Category …………………........ 24

Table 10. Personal Awareness of the SDGs ................................................................ 26

Table 11. Effectiveness of SDGs at Raising Awareness and Leading to Action .......... 26

Table 12. Responses to the Effectiveness of SDGs .................................................... 26

Table 13. Reference to SDGs in Institution Strategic Direction or Plan ....................... 27

Table 14. Inclusion of SDGs in Design Program Curricula ……………………......... 28

Table 15. Examples of SDGs in Design Program Curricula .......................................... 28

Table 16. Individuals Responsible for Introducing New Initiatives to Curricula ......... 29

Table 17. Responses to Introducing SDGs to Curricula .............................................. 29

Table 18. Effectiveness of SDGs as Tool for Teaching SD in Design.......................... 30

Table 19. Responses to Effectiveness of SDGs as Tool for Teaching SD in Design.... 30

Table 20. Discussion of SDGs in Design Community .................................................... 31

Table 21. Effectiveness of Des. Assoc. at Promoting SDGs, Engaging Educators....... 32

Table 22. Responses to Effectiveness of Design Associations ..................................... 32

Table 23. Identified Design Associations ....................................................................... 33

Table 24. How Des. Assoc. Might Raise Awareness and Engage Design Educators ... 34

Table 25. Discussion of SD in Design Community.................................................. 35

Table 26. Responses to Discussion of SD in Design Community................................. 36

Table 27. Consideration of SD in Professional Projects ................................................. 37

Table 28. Examples of SD in Professional Projects ....................................................... 37 
Table 29. Reference to SD in Institution Strategic Direction or Plan ......................... 38

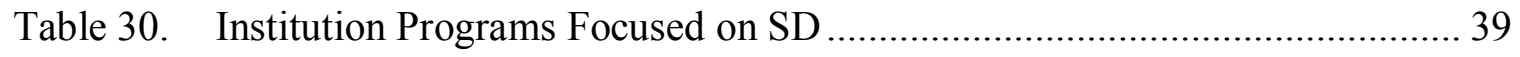

Table 31. Inclusion of SD Concepts in Design Program Curricula .............................. 40

Table 32. Examples of SD Concepts in Design Program Curricula ............................ 40

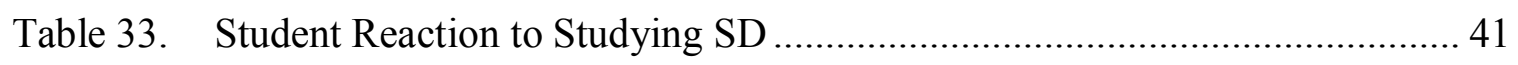

Table 34. Responses to Student Reaction to Studying SD ..................................... 42 


\section{List of Figures}

Figure 1. The effect of human activity on planetary boundaries ..................................... 2

Figure 2. The United Nations Sustainable Development Goals .................................. 12

Figure 3. Sample of design programs and interview participants by province ............. 20

Figure 4. Awareness of SDGs and their effectiveness as an SD initiative ................... 43

Figure 5. Emerging themes from fifty-eight program descriptions by mention ........... 44

Figure 6. Inclusion of SDGs and SD in design program curricula ............................... 45

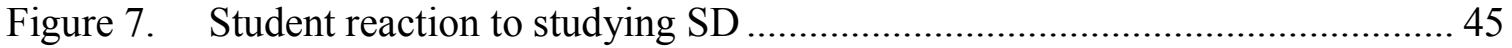

Figure 8. Reference to SDGs and SD in strategic plan............................................... 46

Figure 9. Discussion related to SDGs and SD in design community ........................... 47

Figure 10. Consideration for SD in industry projects .................................................. 48

Figure 11. Network between design associations, community, and program ................ 50

Figure 12. Proposed toolkit for introducing SDGs into design program curricula......... 50

\section{List of Appendices}

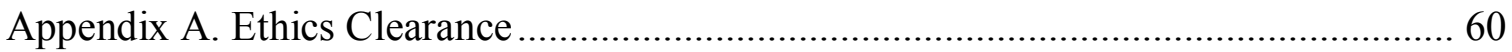

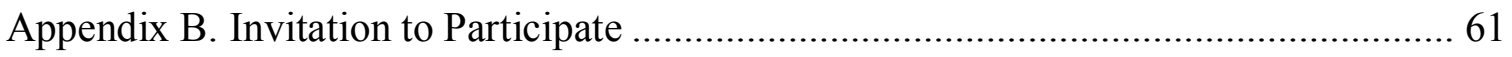

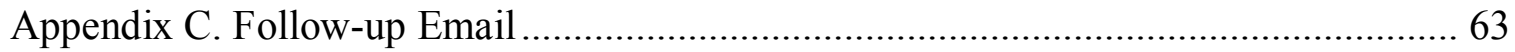

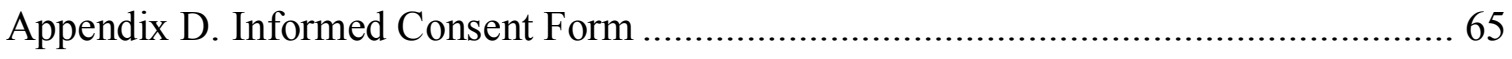

Appendix E. Interview Questions ........................................................................ 71 


\section{List of Abbreviations}

ACID Association of Canadian Industrial Designers

ACIDO Association of Chartered Industrial Designers of Ontario

ADIQ Association des designers industriels du Québec

CMEC Council of Ministers of Education of Canada

DEC Diplôme d'études collégiales

DESD Decade of Education for Sustainable Development

ESD Education for Sustainable Development

GDC Society of Graphic Designers of Canada

IAU International Association of Universities

ICOD International Council of Design

IDC International Design Congress

MDGs Millennium Development Goals

RGD Association of Registered Graphic Designers

SD Sustainable Development

SDGs Sustainable Development Goals

SDGQ Société des designers graphiques du Québec

UN United Nations

UNCSD United Nations Conference for Sustainable Development

UNESCO United Nations Educational, Scientific and Cultural Organization

WDO World Design Organization

WCS World Conservation Strategy 


\section{Preface}

The idea for this research came about over a dinner of Gogigui with Dr. Thomas Garvey at the end of the 2015 International Design Congress (IDC), in Korea. The theme of the conference was Eeum, Korean for connection or join. For seven days, keynotes, talks, and activities called for the collaboration of disciplines in both public and private sectors to move towards a more sustainable future. At the World Design Organization (WDO) general assembly, newly elected president Mugendi M'Rithaa introduced the SDGs, and emphasized the importance of engaging young designers in achieving the ambitious 2030 targets.

We resonated with the IDC and WDO message. The School of Industrial Design at Carleton University had embedded SD in both undergraduate and graduate programs, and we were at that time just starting to explore the SDGs. As we sat eating our barbecue pork on the other side of the planet, we wondered whether other design programs in Canada were also discussing SD and the SDGs. Taking the SDGs at face value as a strategy for achieving SD objectives, and sensitive to the fact they were only recently introduced, we returned to Ottawa to find out. 


\section{Introduction}

\subsection{Background and Scope}

Human activity and natural resource usage since the industrial revolution have surged. Population growth, affordable energy, increased consumption, and the rise of liberal economies have been driving forces, accelerated by global connectivity, communication, and access to knowledge (Costanza et al., 2007). According to Daly (2007, p. 12), "relying on growth in this way might be fine if the global economy existed in a void, but it does not. Rather the economy is a subsystem of the finite biosphere that supports it".

As the economy expands beyond the limits of the biosphere, man-made capital will begin to sacrifice natural capital. Since 1900, the human population has multiplied 4.5 times, from 1.6 billion people to 7.3 billion in 2015 , and is projected to reach 8.5 billion by 2030 (United Nations Department of Economic and Social Affairs, 2015). World Domestic Product is projected to increase to $\$ 272$ trillion by 2050 , or 3 times that of 2010 (Sachs, 2015). According to Steffen et al. (2015), human activity has pushed beyond safe planetary boundaries and has started to put biosphere integrity, land-system change, the climate, and biochemical flow at risk — a strain that has effected human and natural systems, and worldwide quality of life (Barney, 1980; Intergovernmental Panel on Climate Change, 2014). Clearly human activity and use of natural resources must be reconciled with the limitation of the biosphere (Figure 1). 


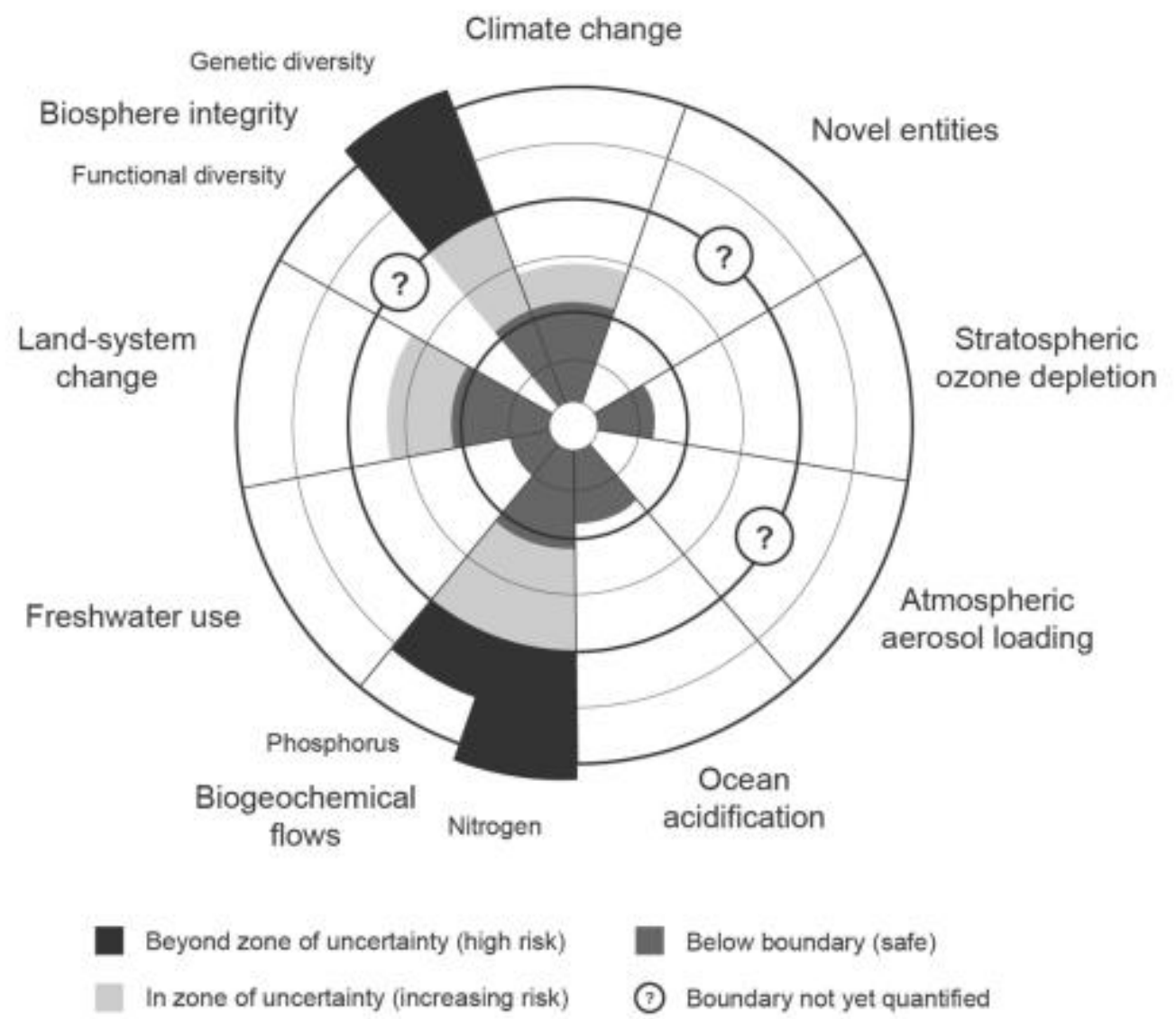

Figure 1. The effect of human activity on planetary boundaries (Steffen et al., 2015).

Sustainable development (SD) is an approach to economic growth that is aware of both the environment and society. According to Sachs (2015, p. 505) "sustainable development is the greatest, most complicated challenge humanity has ever faced". To overcome this challenge humanity will need to think differently (Daly, 2007). SD is not just the theoretical examination of the economy, environment, and society in relation to each other and planetary limitations, but a scientific and technological methodology for solving problems (Sachs, 2015). It is both a field of study, and an underlying mental model applicable to all subjects (McKeown et al., 2002). 
There have been several global efforts to raise awareness and affect policy change towards SD. The United Nations (UN) Millennium Development Goals (MDGs) helped reduce extreme poverty, and increased enrollment of primary school children in developing nations (UN, 2015a). The Decade of Education for Sustainable Development (DESD) spread SD to all levels of education, and encouraged higher education institutions to include SD in their strategic plans (United Nations Educational, Scientific and Cultural Organization, 2014). Most recently, the Sustainable Development Goals (SDGs) are a set of 17 economic, environmental, and societal objectives to achieve SD by 2030 (UN, 2015b).

Design is a methodology for solving problems (Schön, 1987). Global design associations have referenced SD in their strategies (one has made direct mention of the SDGs), and have highlighted the role of young designers in achieving SD (ICOD, 2017; WDO, 2017a; WDO, 2017c). Design programs (we use design program and design school interchangeably) prepare students to solve complex problems (Schön, 1987). What is missing from the literature is data on how these programs are preparing students to tackle SD challenges.

\section{$1.2 \quad$ Purpose of Study}

The purpose of this study is to explore how Canadian design programs have considered SD and the SDGs in their curricula. There was considerable conversation at the International Design Congress about the role of young designers in overcoming SD challenges, and the need for a global, collaborative effort between the professional design community, academia, governments, and industry in achieving the SDGs by 2030 . We were curious if regional industrial and graphic design programs were having the same 
conversation.

The focus is on three- and four-year industrial and graphic design programs in Canada to be insightful to my career as a design educator. I teach interaction design in a graphic design program at a college in Ontario, and am an MDes student at an industrial design school in the same province. Interaction design is a discipline spanning both graphic and industrial design practices. Findings from this research will not only benefit curriculum development for my courses, but that of the faculty of the industrial design program where I study.

\subsection{Research Question}

This is a preliminary study, and has been developed to explore SD and the SDGs in relation to design programs as per the following research question:

To what extent have the United Nations Sustainable Development Goals been included in Canadian industrial and graphic design school curricula?

After reviewing the literature, several themes emerged that led to specific questions that helped put the research into context:

- What are design school perspectives on the SDGs?

- Have design schools included the SDGs in their curricula?

- Have universities and colleges included the SDGs in their strategic plan?

- What are professional design community perspectives on the SDGs?

\subsection{Contributions to the Field}

Findings from this study will be of value to industrial and graphic design educators interested in SD and the SDGs. It will provide them useful information about how design programs across Canada have developed SD and the SDGs into their 
curricula, and will help us identify barriers to implementation. On a broader scale, this study will provide post-secondary institutions and professional design associations a view of SD and the SDGs from the perspective of their affiliated design programs, which might inform future initiatives.

Human growth exceeding the finite limitations of the planet is perhaps the most pressing matter of modern history. The next generation of designers will require the skills to address SD challenges. Findings from this research will help design educators position their program in relation to global SD initiatives. 


\section{$2 \quad$ Literature Review}

\subsection{The Pillars of Sustainability}

The term sustainable development was coined by the World Conservation Strategy (WCS), a strategic document published in 1980 by the International Union for Conservation of Nature and Natural Resources (IUCN) that underlined the risk of ecological instability and quality of life (especially in the developing world) due to exponential economic and population growth in contrast to finite natural resources (Barney, 1980; IUCN, 1980). The aim of the WCS was to "help advance the achievement of sustainable development through the conservation of living resources" (IUCN, 1980, p. iv). The document argued a lack of ecological conservation would lead to socioeconomic problems, such as inflation, unemployment, hunger, and disease. It provided a framework for national and sub-national SD strategies, and recommendations on how to overcome conservation obstacles. Unfortunately, the WCS received a mixed response, having failed to engage policy makers and capture the attention of a public who had little perceived link between resource conservation and SD (Selman, 1985).

The pillars of sustainability were defined after the formation of the World Commission on Environment and Development (WCED). Established in 1983 as a branch of the UN, the commission (also known as the Brundtland Commission) was tasked with drafting an SD framework by the year 2000 (Grober, 2012). Commission chair Gro Harlem Brundtland was critical of the sustainability movement of the early $80 \mathrm{~s}$ that had failed to capture the attention of government policy makers and business leaders, and was instrumental in the publication of Our Common Future (WCED, 1987). Drawing from a comprehensive panel of advisors, the document suggested overpopulation, social 
inequality, and the depletion and misuse of natural resources were linked to environmental problems. According to Caradonna (2012, p. 143), “Our Common Future probably deserves much of the credit for establishing the three Es (environment, economics, and social equality) as the basic model of a sustainable society".

Overpopulation had been identified as a recurring problem since the industrial revolution. Influenced by early population essayists such as Vogt and Osbourn, Ehrlich's (1968) The Population Bomb warned existing populations were underfed and growing, a problem that would result in worldwide starvation and put a strain on the natural environment (Desrochers \& Hoffbauer, 2009). The bestselling book The Limits to Growth by Meadows, Meadows, Randers and Behrens (1972) created computer simulations to demonstrate exponential human and economic growth would eventually surpass the finite ecological limitations of the planet unless countered by significant technological, cultural, and institutional change. Evidence suggests we have already begun to exceed the ecological limits of the planet. Anthropogenic emissions due to human activity have warmed the atmosphere and oceans, diminishing snow and ice, and have increased sea levels (Intergovernmental Panel on Climate Change, 2014). Biosphere integrity, land-system change, and biochemical flows have all passed safe parameters (Steffen et al., 2015).

According to Sachs (2015), the solution is not to limit growth, but to change our habits. By moving to clean energies and improving agricultural techniques, and by leveraging economic policies to overcome externalities, we can begin to reconcile the economy with planetary limits, address societal concerns, and create a more sustained development. 


\subsection{Higher Education and Sustainable Development}

The role of education in achieving SD objectives emerged at the UN Conference on the Human Environment in 1972. The conference was a major milestone in the history of international collaboration on environmental and social issues, the outcome of which was the creation of the United Nations Environment Program, an agency advocating international environmental policies, and the Stockholm Declaration, a collection of proclamations, principles, and recommendations to protect the environment and address social issues (Caradonna, 2014). Recommendation 96 of the declaration formally recognized the role of education in attaining SD objectives (UN, 1972).

Education for sustainable development (ESD) considers methods for achieving sustainable outcomes, whereas education about sustainability is a theoretical discussion. Both are central to raising public awareness of SD, and educating future decision makers and societal leaders in sustainable practice (McKeown et al., 2002). As per the WCS, curricula should "include environmental education both as an intrinsic part of other subjects, so that conservation attitudes can influence all activities, and as a separate subject so that ecology can be taught more formally and its concept more readily grasped" (IUCN, 1980, ch. 13, p. 11).

Today there are several SD related courses and degree programs in higher education, but strategically institutions have been sluggish to reorient their mental models towards the inclusion of SD across all programs. Lozano et al. $(2013 ; 2015)$ compared and analyzed the most commonly referenced higher education declarations from 1990 to 2009 including the Talloires Declaration, signed shortly after the publication of the Brundtland Report, and the Halifax Declaration in Canada. Thematically, the 
declarations discussed the pillars of sustainability, as well as the ethical and moral obligation of universities to include SD in their curricula. The Lozano et al. $(2013 ; 2015)$ studies suggested signing declarations and similar strategies led to some SD activities, but that universities still maintained traditional strategic plans that did promote the inclusion of SD across all academic programs. The authors were critical of universities at lagging behind corporations and society on SD issues, and proposed they take a leading role by introducing SD into all courses, curricula, and institutional activities.

The Higher Education Sustainability Initiative, a group of some 300 universities worldwide, conducted a similar study. Formed shortly after the 2012 UN Conference on Sustainable Development (UNCSD), the group reviewed the progress of all 272 conference commitments, and found $73 \%$ of academic institutions made some direct or indirect progress in the form of strategic plans, working groups, and reporting mechanisms that support SD outcomes (Simon \& Haertle, 2014). However, they underscored the need for these institutions to make a greater effort in promoting SD across all curricula.

\subsection{Higher Education and Sustainable Development Goals}

The role of education in achieving SD objectives has been recognized by global strategies and initiatives. For example, Earth Summit, hosted in Rio de Janeiro and attended by thousands of Non-Governmental Organizations and UN member nations, yielded two non-binding documents: the Rio Declaration, an international directive on development and the environment; and Agenda 21, a framework for SD. Although Earth Summit prompted international adoption of SD principles, implementation was slow, and social and environmental problems continued to decline (Harding, 2006). Nonetheless, 
the conference did help promote ESD. Chapter 36 of Agenda 21 recommended the reorientation of formal education, public awareness, and training towards SD, a concept furthered in 2002 at the World Summit on Sustainable Development in Johannesburg. Three themes emerged from the summit: an emphasis on collaboration; a push to implement sustainability concepts; and a proposed decade of ESD (Harding, 2006). By December of that year, the UN General Assembly appointed the United Nations Educational, Scientific and Cultural Organization (UNESCO) to direct the Decade of Education for Sustainable Development (DESD). Addressing the pillars of sustainability, the DESD ran from 2005 to 2014 with an overall goal to "integrate the principles, values and practices of sustainable development into all aspects of education and learning" (UNESCO, 2017, “Mission”).

The 2014 World Conference on ESD marked the end of the DESD and the signing of the Aichi-Nagoya Declaration, an agreement by participating organizations to implement the Global Action Programme on ESD — a roadmap to identify actionable initiatives and underline the role of higher education in leading a societal paradigm shift towards SD. The DESD final report, Shaping the Future We Want, found the DESD spread ESD across the world to all levels of education, and encouraged higher education institutions to commit to SD in their strategic plans (UNESCO, 2014). The report identified three challenges moving forward: coordination of all levels of the institution, from governance to academic programs; increased staff development to help transition curricula and pedagogy; and the removal of cross-disciplinary boundaries that impede the exploration and learning of complex issues.

Concurrent to the DESD was the signing of the UN Millennium Declaration in 
2002 by one hundred and eighty-nine UN member states agreeing to a deadline of 2015 to collaborate towards eight actionable global targets to overcome extreme poverty in the developing world. What came to be known as the Millennium Development Goals (MDGs) produced a major global effort that helped reduce under-five mortality rates, gained traction in the fight against deadly diseases, reduced the number of people living in extreme poverty, and increased primary school enrollment in developing nations (UN, 2015a). But the MDGs final report also suggested there was a considerable amount of work ahead. In his forward, UN Secretary-General Ban Ki-Moon said the MDGs demonstrated our understanding of how to approach SD challenges, but advised future initiatives would require significant political determination and a global effort "to tackle root causes and do more to integrate the economic, social and environmental dimensions of sustainable development" (UN, 2015a, p. 3). Others were critical of the MDGs focusing exclusively on improving access to primary education, arguing all levels of education were integral to achieving the MDGs and global well-being (Beall, 2013; Kotecha, as cited in MacGregor, 2010).

The 2030 Agenda for Sustainable Development was created in recognition of the shortcomings of the MDGs, and as a new vision for SD. Meeting at the UNCSD, leaders from around the world looked back on more than 40 years since the publication of The Limits to Growth and more than 20 years since Earth Summit, and found the challenges of balancing the pillars of sustainability had not been overcome, and that human activity continued to exceed the limitations of the biosphere as predicted (Sachs, 2015). All one hundred and ninety-three member states of the UN General Assembly adopted the 17 SDGs on September 25, 2015 (Figure 2). Addressing the pillars of sustainability, and 
monitored by a set of indicators, each goal includes a subset of individual targets to reach by 2030 (UN, 2015b).
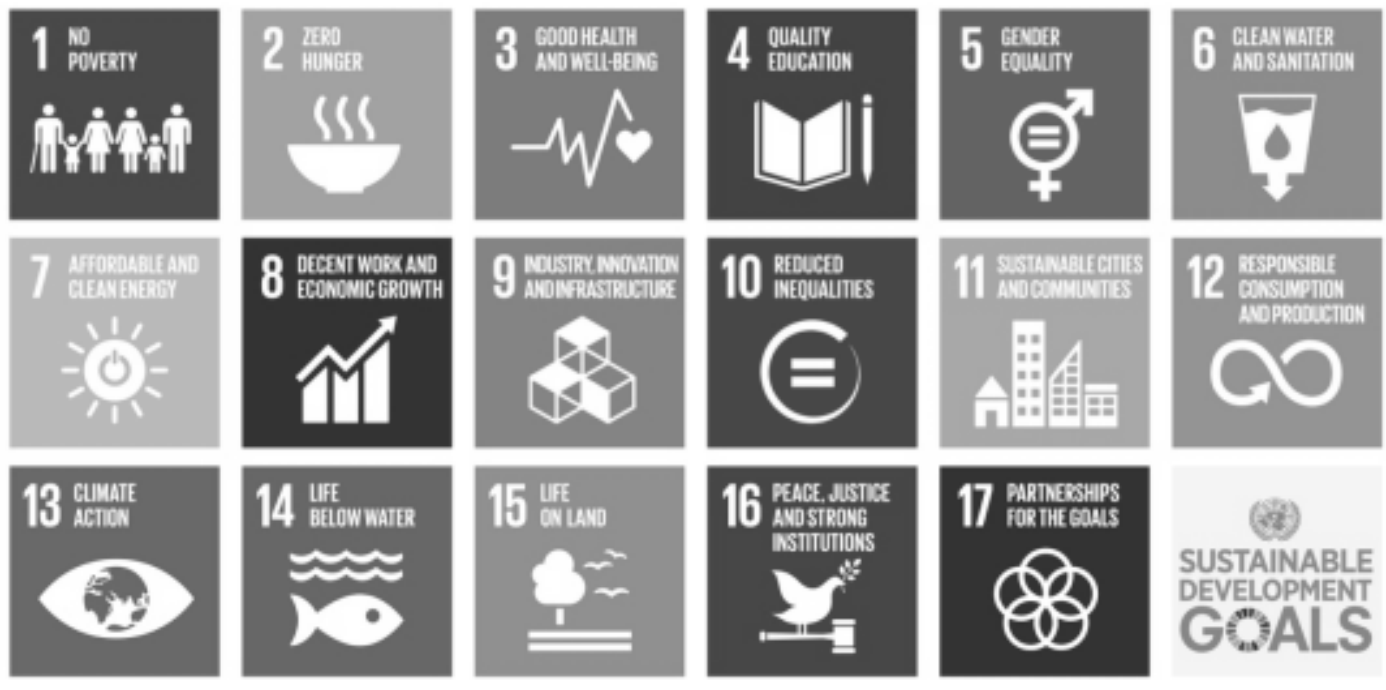

SUSTAINABLE DEVELOPMENT GEALS

Figure 2. The United Nations Sustainable Development Goals (UN, 2017c).

The SDGs are relatively new, but the reaction of higher education institutions appears to be positive. The International Association of Universities (IAU), a UNESCO partner with over six hundred and fifty university members around the world (including 14 from Canada), actively promote the role of higher education in achieving the SDGs by 2030. The IAU conducted a global survey of member leaders, directors, and project coordinators to determine how their institution approached SD. According to their findings (based on IAU member participation of $18 \%$ ), $70 \%$ of respondents either knew well or very well about the SDGs and ESD, and 58\% knew well or very well about the 2030 agenda. Thirty-four percent had included SD in their strategic plan, with an additional $38 \%$ in the process of doing so, and $45 \%$ had adopted a holistic approach to including SD at their institution (IAU, 2016). 
Similar studies have been conducted in Canada. For example, Vaughter et al. (2015) researched ESD policies, declarations, and practices in higher education, and found only $50 \%$ of all 220 accredited Canadian colleges and universities had an environment or sustainability policy. On further analysis of the data, Beveridge et al. (2015) identified 105 institutions that had signed at least one ESD related declaration, but noted the relationship between signing a declaration and implementing ESD initiatives was weak. Near the end of the DESD era, the Council of Ministers of Education of Canada (CMEC), in collaboration with the Canadian-based International Institute for Sustainable Development, surveyed deans and department chairs of 36 institutions across the country. They found the DESD was effective at helping faculty evangelists discuss and act on ESD, however, there was disparity between these early adopters and facultywide responses (CMEC, 2012).

\subsection{Design Associations and Sustainable Development}

Sachs (2015, p. 509) defined SD as "a process, a way of solving problems peacefully and globally, using our science and technology, our know-how". Designers use a similar approach. Schön (1987, loc. 3489$)$ described the design practitioner as an individual who can "solve well-formed instrumental problems by applying theory and technique derived from systematic, preferably scientific knowledge", and had a vision of design schools networking with their universities, and professional design communities. The rebranding and export of design methodology as design thinking to traditionally nondesign disciplines and schools, such as business, is evidence of the effectiveness of design at solving complex problems (Martin, 2009).

$\mathrm{SD}$ is included in the values of design practice, as demonstrated by the strategic 
direction of global design associations. Focused on industrial design, the World Design Organization (WDO; formerly the International Council of Societies of Industrial Design) has a vision to "create a world where design enhances our economic, social, cultural, and environmental quality of life" (WDO, 2017a, "Vision and Mission"). The SDGs are featured prominently below the WDO vision and mission statements, and are a key question in their student interviews which asks, "of the 17 SDGs, which do you believe represent the most important challenges facing your generation today?" (WDO, 2017b, "Stories"). The role of young designers in achieving the WDO vision and mission was front-and-centre at World Industrial Design Day 2016. Themed "Youth in Design", the WDO-organized event commenced with an open letter from the board of directors highlighting the rise of design-forward companies, and a new generation of designers embracing SD values (WDO, 2017c).

Focused on graphic and communication design, the International Council of Design (ICOD) promotes design as a means of improving the well-being of humanity. According to their president, designers are tied to globalization, and have a responsibility to "understand the economic, social, cultural and political implications of globalization on society and on our individual professional situations" (ICOD, 2017, "News \& Views"). In his opinion, the role of ICOD was not only to champion the value of design in overcoming global challenges, but to support the evolution of design curriculum towards the needs of future designers.

Canadian design associations have also included SD in the values of design practice. The Association of Canadian Industrial Designers (ACID) defines industrial design as an activity that is central to global sustainability and human well-being (ACID, 
2017). According to the Association of Chartered Industrial Designers of Ontario (ACIDO), industrial design "has a starring role in the economic, social and environmental well-being of our communities and our nation" (ACIDO, 2017, "Industrial Design"). In western provinces, the Society of Graphic Designers of Canada (GDC) have a committee dedicated to sustainability in communication, and in eastern provinces the Association of Registered Graphic Designers (RGD) hosts the Social Good Design awards, a celebration of the power of design in making meaningful change in society (GDC, 2017; RGD, 2017). In Québec, the Association des designers industriels du Québec (ADIQ) not only positions industrial design within the economy and society, but includes SD as a part of learning the discipline, and the Société des designers graphiques du Québec (SDGSQ) encourages design professionals to adopt a responsible practice that considers the environment, people, community and future generations (ADIQ, 2017; SDGSQ, 2017). Each of these design associations support industrial and graphic design education respectively, and are affiliated with design schools in their region.

Global and regional design associations have included SD in the values of design practice, and both the WDO and ICOD underline the role of education in achieving SD objectives. What remains unknown is to what extent Canadian industrial and graphic design programs are themselves aware of the SDGs, and whether they have included SD in their curricula. Furthermore, there is no literature on whether these schools are networked with their institution and design community. Our study aims to investigate these areas. 


\section{$3 \quad$ Methods}

The purpose of this study was to explore the extent to which SD and the SDGs had been included in three- and four-year Canadian industrial and graphic design program curricula.

The study was divided into two parts. The first part examined website program descriptions to get a sense of how each program positioned themselves in design practice and aligned with global SD objectives. The second part was a semi-structured interview of program coordinators - individuals in a leadership role with knowledge of both program strategy and curricula development. It was also felt these individuals would be in a good position to comment on not just their respective design programs, but their institution, and design community.

As this was a Canada-wide study, both English and French data were collected. Both French and English course descriptions were analyzed in their original language, and interviews were conducted in the preferred language of each participant. A translator was hired to translate documents into French as needed, and all field notes and thematic coding was conducted in English.

Canadian institutions were identified from databases made available to the public by the WDO, ICOD, GDC, RGD, ADIQ, SDGQ, and by conducting a general online search with the terms "Industrial Design School" and "Graphic Design School" in both languages. The criteria were further limited to industrial or graphic design schools in Canadian university, college or cégep post-secondary institutions with three- to four-year bachelor's degree, advanced diploma, or diplôme d'études collégiales (DEC) programs. The School of Industrial Design at Carleton University was excluded from the study to 
avoid bias.

Industrial and graphic design program course descriptions were taken from the program landing pages of their respective institution websites at the start of the 2016 fall semester. Descriptions were copied and pasted into a Microsoft Word document and loaded into QSR International NVivo as individual cases for analysis. Each institution was assigned a code to remain anonymous at the time of analysis and publication. The theoretical approach to our qualitative analysis was based on grounded theory (Glaser \& Strauss, 1967). Themes were identified and organized into groups. After several rounds of analysis, prominent themes were summarized, then categorized as common or unique using a matrix (Bernard, 2006). Phrase frequency was included in the matrix.

After receiving ethics clearance, coordinators were identified by reviewing information made public by their institution online (Appendix A). Coordinators were invited to participate in the study via email, and after expressing interest were forwarded a follow-up email with the informed consent form, survey questions, and links to information regarding the SDGs (Appendix B; Appendix C; Appendix D). There were a couple of cases where the program coordinator was unable to participate in the study, but recruited a colleague who was equally as knowledgeable about the program. Of the schools that met the criteria, approximately half participated in the interview part of the study, and all interviews were completed successfully.

The survey instrument was a two-part questionnaire conducted as a phone interview (Appendix E). Data were collected over a period of three months. Each participant was assigned a code to keep their identity and institution anonymous at the time of analysis and publication. Interviews were approximately twenty to thirty minutes 
in length, and recorded using audio software and field notes. If the field notes required clarification, the audio recording was referenced. The first ten questions focused on the SDGs specifically, and the last five explored SD themes in general. Nominal data was collected in the form of multiple choice answers (except for one question that asked participants for a solution to a possible problem). Most of the questions had a qualitative follow-up component to further explore participant answers. Data collected from multiple choice answers were analyzed using IBM SPSS. Descriptive statistics were used to identify frequencies and compare variables with tables. Field notes from the qualitative answers were loaded into QSR International NVivo and analyzed using the same technique as the program descriptions. 


\section{$4 \quad$ Findings}

\subsection{Sample}

The sample of schools that met the criteria as defined in the methods section of this study was $n=58$. Table 1 groups schools by type and academic accreditation. Table 2 identifies the schools according to their province.

Table 1

Sample of Design Programs by Accreditation

\begin{tabular}{llll}
\hline & Degree & Diploma & DEC \\
\hline Industrial Design & 9 & 0 & 4 \\
Graphic Design & 18 & 20 & 7 \\
Total Sample $(n=58)$ & 27 & 20 & 11 \\
\hline
\end{tabular}

Table 2

Sample of Design Programs by Province

\begin{tabular}{lll}
\hline & Industrial Design & Graphic Design \\
\hline Alberta & 1 & 5 \\
British Columbia & 2 & 6 \\
New Brunswick & 0 & 1 \\
Nova Scotia & 1 & 0 \\
Ontario & 3 & 22 \\
Québec & 6 & 11 \\
Total Sample $(n=58)$ & 13 & 45 \\
\hline
\end{tabular}

There was some variance in the name and accreditation of industrial and graphic design programs. Industrial design programs were the most consistent, with program names varying between industrial design, product design, and design studies, and accreditation favouring a bachelor degree $(n=9)$ in arts, design, or industrial design, except for Québec which also offered a DEC $(n=4)$. Graphic design program names ranged from graphic design to visual communication to design studies, and offered about 
the same amount of degrees $(n=18)$ as diplomas $(n=20)$, except for Québec which offered a DEC $(n=7)$ instead of a diploma. A review of each program web page helped to further categorize each program. As an additional criterion, only industrial design programs focused on product outcomes were included, and only graphic design programs focused on visual communication for print and digital medias were included. This was the sample used in the evaluation of the course descriptions (Figure 3).

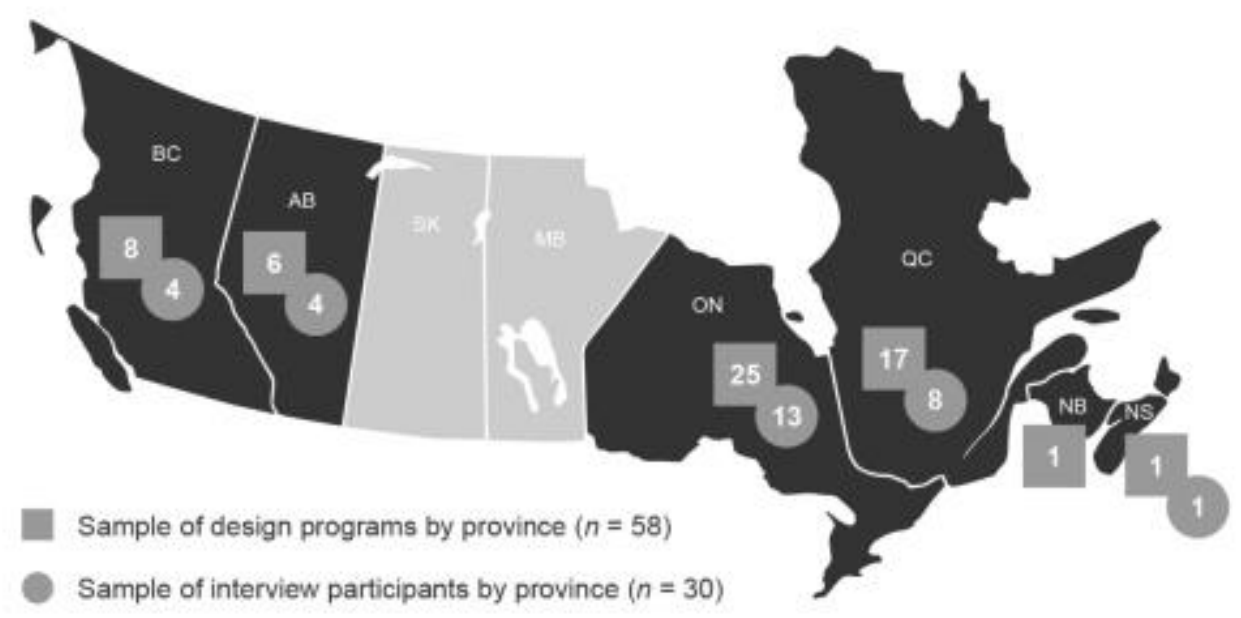

Figure 3. Sample of design programs and interview participants by province.

The interviews were a smaller sub-set of this sample. Of the fifty-eight invitations that were sent to post-secondary institutions that met the above criteria, about half ( $n=$ 30) agreed to participate, and were interviewed successfully. The breakdown of this sample sub-set is described in Tables 3 and 4. About one-third were industrial design programs $(n=11)$, and two-thirds graphic design programs $(n=19)$. 
Table 3

Interview Participants by Accreditation

\begin{tabular}{llll}
\hline & Degree & Diploma & DEC \\
\hline Industrial Design & 8 & 0 & 3 \\
Graphic Design & 9 & 10 & 0 \\
Total Sample $(n=30)$ & 17 & 10 & 3 \\
\hline
\end{tabular}

Table 4

Interview Participants by Province

\begin{tabular}{lll}
\hline & Industrial Design & Graphic Design \\
\hline Alberta & 1 & 3 \\
British Columbia & 2 & 2 \\
New Brunswick & 0 & 0 \\
Nova Scotia & 1 & 0 \\
Ontario & 2 & 11 \\
Québec & 5 & 3 \\
Total Sample $(n=30)$ & 11 & 19 \\
\hline
\end{tabular}

\subsection{Course Descriptions}

The first round of analysis was an exact keyword query. As demonstrated in Table 5, the term "sustainable development" was found in twelve of the program descriptions, and the term "sustainability" found in five.

Table 5

Exact Keyword Search of Design Program Descriptions

\begin{tabular}{ll}
\hline Exact Keywords & $\mathrm{n}$ \\
& \\
\hline "Sustainable Development" & 12 \\
"Sustainability" & 5 \\
\hline
\end{tabular}

The second round of analysis was coding the course descriptions to identify recurring themes. Using NVivo, two thematic categories emerged. Content related to students and the program were categorized as program, whereas content related to design 
practitioners and the profession were categorized as profession. Each category was then further divided into themes. As demonstrated in Table 6, all descriptions $(n=58)$ provided information relevant to the program, and discussed the student experience.

About half $(n=28)$ discussed aspects of the design profession.

Table 6

Thematic Categories Identified in Program Descriptions

\begin{tabular}{llc}
\hline Category & Common & $\mathrm{n}$ \\
\hline Program & $\begin{array}{l}\text { Content focusing on student experience and } \\
\text { program information. }\end{array}$ & 58 \\
Profession & $\begin{array}{l}\text { Content focusing on design practitioners and the } \\
\text { profession of design. }\end{array}$ & 28 \\
\hline
\end{tabular}


Table 7

Themes Identified in the Program Category

\begin{tabular}{|c|c|c|}
\hline Theme & Common & $\mathrm{n}$ \\
\hline Applied Skills & $\begin{array}{l}\text { Learning the applied methods, skills and tools of } \\
\text { design practice. }\end{array}$ & 52 \\
\hline Career Prospects & $\begin{array}{l}\text { Industry opportunities and career paths available } \\
\text { upon completion of the program. }\end{array}$ & 43 \\
\hline Critical/Design Thinking & $\begin{array}{l}\text { Leveraging academic theory and conceptual } \\
\text { development methods to make informed } \\
\text { decisions when solving complex problems. }\end{array}$ & 35 \\
\hline Real-world Projects & $\begin{array}{l}\text { Hands-on learning developing projects that reflect } \\
\text { industry practice. }\end{array}$ & 29 \\
\hline Industry Exposure & $\begin{array}{l}\text { Network with highly specialized faculty who } \\
\text { bring industry experience to the classroom. }\end{array}$ & 27 \\
\hline Business of Design & $\begin{array}{l}\text { Business and entrepreneurial strategies and } \\
\text { methods for design practitioners. }\end{array}$ & 24 \\
\hline Studio \& Technology & $\begin{array}{l}\text { Small class sizes hosted in modern studio spaces } \\
\text { with industry equipment and technology. }\end{array}$ & 24 \\
\hline Sustainable Development* & $\begin{array}{l}\text { Highlighting the role of design in overcoming } \\
\text { global challenges. }\end{array}$ & 17 \\
\hline Design Community & $\begin{array}{l}\text { Affiliation with design associations and } \\
\text { participation in professional events. }\end{array}$ & 16 \\
\hline Personal Qualities & $\begin{array}{l}\text { Character traits that typically lead to a successful } \\
\text { tenure in the program. }\end{array}$ & 16 \\
\hline Student Placement & $\begin{array}{l}\text { Opportunity for students to gain industry } \\
\text { experience working in the field. }\end{array}$ & 16 \\
\hline Human/User-centered & $\begin{array}{l}\text { Appreciation for human behaviour and factors } \\
\text { when solving problems. }\end{array}$ & 14 \\
\hline Student Exhibits & $\begin{array}{l}\text { Public exhibition of culminating student design } \\
\text { outcomes. }\end{array}$ & 12 \\
\hline Inter/multidisciplinary & $\begin{array}{l}\text { Combing the skills and knowledge from several } \\
\text { disciplines to solve problems. }\end{array}$ & 11 \\
\hline History of Design & $\begin{array}{l}\text { An examination of events, trends, and seminal } \\
\text { movements in art and design. }\end{array}$ & 9 \\
\hline Student Competitions & $\begin{array}{l}\text { Opportunity to submit projects to academic and } \\
\text { industry run design challenges. }\end{array}$ & 5 \\
\hline
\end{tabular}

*Sub-themes are discussed below. 
Table 8

Themes Identified in the Profession Category

\begin{tabular}{llc}
\hline Theme & Common & $\mathrm{n}$ \\
\hline Design Practice & $\begin{array}{l}\text { An overview of the methods and processes used } \\
\text { by professional designers to create a project. }\end{array}$ & 26 \\
Human/User-centered & $\begin{array}{l}\text { Highlighting how designers create the things we } \\
\text { interact with every day. }\end{array}$ & 7 \\
Business of Design & $\begin{array}{l}\text { Industry growth and demand for the skills } \\
\text { acquired in a design program. }\end{array}$ & 5 \\
Sustainable Development & $\begin{array}{l}\text { Practitioners as change agents, and sensitive to } \\
\text { social, economic, and ecological issues. }\end{array}$ & 5 \\
Inter/multidisciplinary & $\begin{array}{l}\text { Design professionals are versed in various } \\
\text { disciplines and work well with others. }\end{array}$ & 2 \\
\hline
\end{tabular}

The profession Sustainable Development theme discussed design practitioners as either playing a role in overcoming social, economic and ecological challenges, or being sensitive to how their products relate to those issues $(n=5)$. However, the program Sustainable Development theme was much more in-depth, and could be divided into various sub-themes as demonstrated in Table 9.

Table 9

SD Sub-Themes Identified in the Program Category

\begin{tabular}{llc}
\hline Sub-Theme & Common & $\mathrm{n}$ \\
\hline Design as Change & $\begin{array}{l}\text { Role of design and design practitioners in } \\
\text { addressing social, cultural and economic issues. }\end{array}$ & 13 \\
Ecology \& Environment & $\begin{array}{l}\text { Environmental and ecological considerations } \\
\text { baked into project development. }\end{array}$ & 4 \\
Graduate Leaders & $\begin{array}{l}\text { Opportunity for graduates to take leadership roles } \\
\text { in overcoming global challenges. }\end{array}$ & 4 \\
Ethical Responsibility & $\begin{array}{l}\text { Ethical considerations when developing projects } \\
\text { for local and global markets. }\end{array}$ & 3 \\
Principles of SD & Students will learn about the principles of SD & 3 \\
\hline
\end{tabular}




\subsection{Interview}

\subsubsection{First Part}

About half of the sample group $(n=30)$ participated in the study and all interviews were completed successfully. All participants were provided information pertaining to the SDGs before the interview, and were interviewed individually.

Responses to the interview questions reflected the views of the participants.

The first question was designed to measure personal awareness of the SDGs, and helped frame the questions that followed (Table 10). About two-thirds $(n=18)$ of participants indicated they had no knowledge of the SDGs before the study, a third ( $n=$ 10) said they were aware, and only a couple $(n=2)$ said they had good comprehension. The second question asked how effective the SDGs had been at raising global awareness and action towards SD issues (Table 11). A third of respondents $(n=10)$ said the SDGs were somewhat effective, and another third were uncertain at the time of the interview ( $n$ $=10)$. Only a handful $(n=5)$, said the SDGs were effective, and one participant said they were very effective.

To gain some insight into the responses, some of the questions had a qualitative follow-up. Responses to these follow-up questions were coded thematically in NVivo. Themes were then categorized as either common or unique. There was some consensus on the SDGs having effectively identified SD issues, at least as a starting point $(n=9)$, yet the same amount $(n=9)$ questioned how effective the UN had been at communicating the SDGs, since they had not previously heard about them. Some agreed $(n=6)$ the SDGs were very broad and global, and questioned how they would be implemented locally (Table 12). 
Table 10

Personal Awareness of the SDGs

\begin{tabular}{lll}
\hline Response & $\mathrm{n}$ & $\%$ \\
\hline Good comprehension & 2 & 6.7 \\
Aware & 10 & 33.3 \\
No knowledge & 18 & 60 \\
Total & 30 & 100.0 \\
\hline
\end{tabular}

Table 11

Effectiveness of SDGs at Raising Awareness and Leading to Action

\begin{tabular}{lll}
\hline Response & $\mathrm{n}$ & $\%$ \\
\hline Very effective & 1 & 3.3 \\
Effective & 5 & 16.7 \\
Somewhat Effective & 10 & 33.3 \\
Ineffective & 3 & 10.0 \\
Very Ineffective & 1 & 3.3 \\
Uncertain at this time & 10 & 33.3 \\
Total & 30 & 100.0 \\
\hline
\end{tabular}

Table 12

Responses to the Effectiveness of SDGs

\begin{tabular}{llll}
\hline Common & $\mathrm{n} \quad$ Unique & $\mathrm{n}$
\end{tabular}

The SDGs have identified SD issues, 9 The prior MDGs were effective. 1 and are a good starting point to raising awareness.

Communication has not been effective since they had not heard about the SDGs prior to this study.

9 Have referenced them on previous 1 projects and found them to be effective.

The SDGs are very broad. Perhaps good at a global level, but unclear 6 Have been working in the field for 1 some time but never heard of them. how actionable they are locally. 
The third question asked participants if their institution's strategic plan referenced the SDGs (Table 13). Most participants $(n=24)$ said the SDGs were not in their institution's strategic plan, and some said they were uncertain $(n=6)$. In a follow-up question, none identified the SDGs in other initiatives.

Table 13

Reference to SDGs in Institution Strategic Direction or Plan

\begin{tabular}{lll}
\hline Response & $\mathrm{n}$ & $\%$ \\
\hline Yes & 0 & 0.0 \\
No & 24 & 80 \\
Uncertain at this time & 6 & 20 \\
Total & 30 & 100.0 \\
\hline
\end{tabular}

Question four asked participants to what extent the SDGs had been included in their design school curricula. Most participants $(n=25)$ reported they had never included the SDGs in their curriculum, one had rarely included, a few had occasionally included ( $n$ $=3$ ), and one had frequently included (Table 14). Only two participants provided examples of how the SDGs had been included in their curricula (Table 15). The first had students create infographics for a chosen SDGs, and develop a campaign based on whichever SDGs the UN was featuring that year. The second said they would be including the SDGs in an upcoming lecture. A couple of participants $(n=2)$ said their curricula included a different SD strategy, namely the GDC Sustainable Design Values and Principles, and the MDGs respectively. A few mentioned $(n=3)$ the SDGs would fit future courses nicely, and would be something to investigate. 
Table 14

Inclusion of SDGs in Design Program Curricula

\begin{tabular}{lll}
\hline Response & $\mathrm{n}$ & $\%$ \\
\hline Frequently included & 1 & 3.3 \\
Occasionally included & 3 & 10.0 \\
Rarely included & 1 & 3.3 \\
Never included & 25 & 83.3 \\
Total & 30 & 100.0 \\
\hline
\end{tabular}

Table 15

Examples of SDGs in Design Program Curricula

\begin{tabular}{llll}
\hline Common & $\mathrm{n}$ & Unique & $\mathrm{n}$ \\
\hline $\begin{array}{l}\text { SDGs are something to investigate } \\
\text { for future courses. }\end{array}$ & $3 \quad \begin{array}{l}\text { Curricula references the GDC } \\
\text { Sustainable Design Values and } \\
\text { Principles. }\end{array}$ & 1 \\
& $\begin{array}{l}\text { Have used the MDGs in the past. } \\
\text { Students develop projects based on } \\
\text { chosen SDGs. } \\
\end{array}$ & 1 \\
& $\begin{array}{l}\text { The SDGs will be featured in an } \\
\text { upcoming lecture. }\end{array}$ & 1 \\
\hline
\end{tabular}

Questions five through seven explored the challenges of implementing the SDGs into design school curricula. Participants were first asked to select from a list of individuals who would be responsible for introducing new themes into their curricula (Table 16). The responses were approximately distributed into thirds, between deans and chairs $(31.1 \%)$, coordinators and directors $(26.2 \%)$, and professors, lecturers and instructors (33.3\%). Question six was a follow-up to question five, asking participants what challenges they might face if they were to introduce the SDGs to their curricula (Table 17). The top-two challenges identified were the need to raise awareness first to get 
faculty buy-in $(n=14)$, and the time and resources required to introduce new themes and learning outcomes to already dense curricula $(n=14)$. Exactly one-third of participants $(n$ $=10)$ reported there would be no major challenges since faculty and students were already aware of SD, which had already been worked into curricula. It was interesting to note, only one participant said the SDGs would need to align with faculty research, and another said the SDGs would need to be validated against other frameworks.

Table 16

Individuals Responsible for Introducing New Initiatives to Curricula

\begin{tabular}{lll}
\hline Variable $^{\mathrm{a}}$ & $\mathrm{n}$ & $\%$ \\
\hline Presidents \& VPs & 7 & 8.3 \\
Deans \& Chairs & 11 & 31.1 \\
Coordinators \& Directors & 22 & 26.2 \\
Professors, Lecturers \& Instructors & 28 & 33.3 \\
Student Leaders & 11 & 13.1 \\
Other & 5 & 6.0 \\
\hline
\end{tabular}

${ }^{a}$ Dichotomy group tabulated at value 1 .

Table 17

Responses to Introducing SDGs to Curricula

Common $n$ Unique n

Need to raise awareness first to get faculty to buy-in to the inclusion of SDGs to their curricula.

Would require time and resources to introduce new themes and learning

14 Aligning with faculty research 1 outcomes to dense curricula.

No major challenges since faculty and students already aware of SD which is already in curricula.

Getting approval from

administration and/or institution may be a hurdle.

Logistical barriers may be a concern. 3 
The seventh question asked if the SDGs would be an effective tool for teaching SD to design students (Table 18). Many participants were uncertain at the time of the interview $(n=11)$, but there was some agreement on the SDGs being somewhat effective $(n=6)$, and effective $(n=8)$. Only a couple of participants said they were very effective $(n=2)$. In the follow-up question (Table 19), about a third of participants $(n=11)$ said the SDGs were a good framework for critical thinking, but they were unclear how they translated into applied curricula. A few participants $(n=3)$ said teaching resources and materials would be helpful, and some said $(n=6)$ the SDGs were a good reference for writing SD issues into curricula.

Table 18

Effectiveness of SDGs as a Tool for Teaching SD in Design

\begin{tabular}{lll}
\hline Response & $\mathrm{n}$ & $\%$ \\
\hline Very effective & 2 & 6.7 \\
Effective & 8 & 26.7 \\
Somewhat Effective & 6 & 20.0 \\
Ineffective & 2 & 6.7 \\
Very Ineffective & 1 & 3.3 \\
Uncertain at this time & 11 & 36.7 \\
Total & 30 & 100.0 \\
\hline
\end{tabular}

Table 19

Responses to Effectiveness of SDGs as a Tool for Teaching SD in Design

\begin{tabular}{llll}
\hline Common & $\mathrm{n}$ & Unique & $\mathrm{n}$ \\
\hline $\begin{array}{l}\text { Good high-level framework for } \\
\text { critical thinking, but unclear how to } \\
\text { implement into applied curricula. }\end{array}$ & 11 & $\begin{array}{l}\text { Provinces needs to rephrase the } \\
\text { SDGs to make them locally } \\
\text { applicable. }\end{array}$ & 1 \\
$\begin{array}{l}\text { Good high-level framework to } \\
\text { reference when designing curricula. }\end{array}$ & 6 & & \\
$\begin{array}{l}\text { SDGs teaching resources and } \\
\text { materials are necessary. }\end{array}$ & 3 & & \\
\hline
\end{tabular}


The next set of questions related to SDGs in industry and design practice.

Question eight asked each participant how often, in their experience, the SDGs had emerged in professional dialog and media (Table 20). About a half of all respondents $(n=$ 16) said the SDGs had never emerged, and a little over a third $(n=12)$ said they were rarely discussed. Question nine asked how effective professional design associations had been at raising awareness and engaging design school educators with the SDGs (Table 21). About half $(n=16)$ of respondents said ineffective, and about a third $(n=11)$ said very ineffective. When asked to elaborate on their answer, some said $(n=5)$ raising awareness for the SDGs did not appear to be part of the mandate of design associations, and the same amount $(n=5)$ suggested design associations had promoted some aspects of $\mathrm{SD}$ in the past, such as accessibility, but not the SDGs specifically (Table 22). A couple of participants $(n=2)$ wondered if these associations were even aware of the SDGs themselves, and the same number $(n=2)$ said engagement with design educators was lacking. One participant said SD was systemic, and design associations were not doing enough to reach outside of the design field. Question nine asked participants to list the design associations they were affiliated with (Table 23).

Table 20

Discussion of SDGs in Design Community

\begin{tabular}{lll}
\hline Response & $\mathrm{n}$ & $\%$ \\
\hline Always & 0 & 0.0 \\
Frequently & 0 & 0.0 \\
Occasionally & 1 & 3.3 \\
Rarely & 12 & 40.0 \\
Never & 16 & 53.3 \\
Uncertain at this time & 1 & 3.3 \\
Total & 30 & 100.0 \\
\hline
\end{tabular}


Table 21

Effectiveness of Design Associations at Promoting SDGs and Engaging Educators

\begin{tabular}{lll}
\hline Response & $\mathrm{n}$ & $\%$ \\
\hline Very effective & 0 & 0.0 \\
Effective & 0 & 0.0 \\
Somewhat Effective & 3 & 10.0 \\
Ineffective & 16 & 53.3 \\
Very Ineffective & 11 & 36.7 \\
Total & 30 & 100.0 \\
\hline
\end{tabular}

Table 22

Responses to Effectiveness of Design Associations

\begin{tabular}{llll}
\hline Common & $\mathrm{n}$ & Unique & $\mathrm{n}$
\end{tabular}

Does not appear to be part of their $\quad 5 \quad$ SD is systemic, and associations are 1 mandate to raise awareness. not engaging outside of design field.

Associations have promoted some 5 aspects of SD in the past, just not the SDGs specifically.

Associations may not be aware of 2 the SDGs themselves.

Engagement with design educators 2 has not been sufficient. 
Table 23

Identified Design Associations

\begin{tabular}{|c|c|c|c|}
\hline Common & $\mathrm{n}$ & Unique & $\mathrm{n}$ \\
\hline $\begin{array}{l}\text { Association of Registered Graphic } \\
\text { Designers (RGD) }\end{array}$ & 16 & Design Research Society (DRS) & 1 \\
\hline $\begin{array}{l}\text { Society of Graphic Designers of } \\
\text { Canada (GDC) }\end{array}$ & 12 & Design Council & 1 \\
\hline $\begin{array}{l}\text { Association des designers industriels } \\
\text { du Québec (ADIQ) }\end{array}$ & 4 & $\begin{array}{l}\text { International Institute for } \\
\text { Information Design (IIID) }\end{array}$ & 1 \\
\hline $\begin{array}{l}\text { The professional association for } \\
\text { design (AIGA) }\end{array}$ & 3 & $\begin{array}{l}\text { Interaction Design Association } \\
\text { (IxDA) }\end{array}$ & 1 \\
\hline $\begin{array}{l}\text { World Design Organization (WDO, } \\
\text { formerly ICSID) }\end{array}$ & 3 & $\begin{array}{l}\text { Ordre des architectes du Québec } \\
\text { (OAQ) }\end{array}$ & 1 \\
\hline $\begin{array}{l}\text { Association of Chartered Industrial } \\
\text { Designers of Ontario (ACIDO) }\end{array}$ & 2 & & \\
\hline $\begin{array}{l}\text { International Council of Design } \\
\text { (ICOD) }\end{array}$ & 2 & & \\
\hline $\begin{array}{l}\text { Industrial Designers Society of } \\
\text { America (IDSA) }\end{array}$ & 2 & & \\
\hline $\begin{array}{l}\text { Société design designers graphiques } \\
\text { du Québec (SDGSQ) }\end{array}$ & 2 & & \\
\hline
\end{tabular}

The final question of the first part of the questionnaire asked participants for their opinion on how design associations could raise awareness of the SDGs and connect with design programs (Table 24). Over a third of respondents $(n=12)$ said design associations could talk about the SDGs over their existing communication channels, and others $(n=8)$ said talks and discussions at conferences would be a good opportunity to raise awareness. Student competitions were mentioned $(n=7)$, as was increased interaction with design educators and students $(n=6)$, and hosting workshops for faculty and students $(n=6)$. Some participants $(n=4)$ suggested the SDGs could be featured in association mission/vision statements and core values, and a few suggested associations could learn 
from what design schools were doing $(n=3)$. A couple of participants $(n=2)$ said associations should be working in local neighborhoods to identify problems and build bridges between programs and communities.

Table 24

How Design Associations Might Raise Awareness and Engage Design Educators

\begin{tabular}{|c|c|c|c|}
\hline Common & $\mathrm{n}$ & Unique & $\mathrm{n}$ \\
\hline $\begin{array}{l}\text { Raise awareness by promoting the } \\
\text { SDGs in communication channels } \\
\text { such as website, forums, brochures } \\
\text { and newsletters. }\end{array}$ & 12 & $\begin{array}{l}\text { A declaration signed by all } \\
\text { associations promoting the SDGs. }\end{array}$ & 1 \\
\hline $\begin{array}{l}\text { Include more SDGs related talks and } \\
\text { discussions at conferences. }\end{array}$ & 8 & $\begin{array}{l}\text { Form a committee dedicated to } \\
\text { sustainability and the SDGs. }\end{array}$ & 1 \\
\hline $\begin{array}{l}\text { Establish student competitions and } \\
\text { awards themed around the SDGs. }\end{array}$ & 7 & $\begin{array}{l}\text { Provide information on how to talk } \\
\text { to clients about SDGs. }\end{array}$ & 1 \\
\hline $\begin{array}{l}\text { Form a relationship with design } \\
\text { educators and students to discuss } \\
\text { these issues in relation to curricula. }\end{array}$ & 6 & $\begin{array}{l}\text { Provide information in both French } \\
\text { and English. }\end{array}$ & 1 \\
\hline $\begin{array}{l}\text { Host on and off campus SDGs } \\
\text { workshops for faculty and students. }\end{array}$ & 6 & & \\
\hline $\begin{array}{l}\text { Make the SDGs part of mission or } \\
\text { vision statements and core values. }\end{array}$ & 4 & & \\
\hline $\begin{array}{l}\text { Design associations need to learn } \\
\text { from what design schools are doing. }\end{array}$ & 3 & & \\
\hline $\begin{array}{l}\text { Work in local communities to } \\
\text { identify problems and create bridges. }\end{array}$ & 2 & & \\
\hline
\end{tabular}

\subsubsection{Second Part}

The second part of the questionnaire explored how design programs had included general or common SD issues into their curricula. Many of these questions were similar to those in the first part. 
The first question asked how often SD was discussed as a topic in industry (Table $25)$. According to roughly two-thirds of respondents $(n=18)$, SD was discussed frequently, and about a third $(n=11)$ said it was discussed occasionally. Only one participant said SD was always discussed. When asked why there was this much conversation around $\mathrm{SD}$, over a third $(n=12)$ of participants said the public had become aware of planetary problems, and see the need for sustainable solutions (Table 26). Some participants $(n=7)$ said designers were positioned to take a leadership role in championing SD, and a handful said SD leadership could be seen from corporations $(n=$ $5)$, clients $(n=4)$ and consumers $(n=3)$. A pair of respondents $(n=2)$ said conferences typically featured some form of SD discussion. By contrast, there were a few participants $(n=3)$ who said there was global awareness but little action, and a couple $(n=2)$ who said it was hard to include sustainable practices when profit remained the main driver. Another pair of participants $(n=2)$ said people were bombarded with so much other information it became hard to focus on what was important. Unique to these answers was one participant who said SD had always been part of design dialog, one who said older designers had a hard time letting go of traditional practices and do not see the importance of $\mathrm{SD}$, and another who said SD was becoming a way of thinking.

Table 25

Discussion of SD in Design Community

\begin{tabular}{lll}
\hline Response & $\mathrm{n}$ & $\%$ \\
\hline Always & 1 & 3.3 \\
Frequently & 18 & 60 \\
Occasionally & 11 & 36.7 \\
Rarely & 0 & 0.0 \\
Never & 0 & 0.0 \\
Total & 30 & 100.0 \\
\hline
\end{tabular}


Table 26

Responses to Discussion of SD in Design Community

\begin{tabular}{|c|c|c|c|}
\hline Common & $\mathrm{n}$ & Unique & $\mathrm{n}$ \\
\hline $\begin{array}{l}\text { Public has become aware of } \\
\text { planetary problems and see the need } \\
\text { for SD. }\end{array}$ & 12 & $\begin{array}{l}\text { SD has always been a part of design } \\
\text { dialog. }\end{array}$ & 1 \\
\hline $\begin{array}{l}\text { Designers are positioned to inform } \\
\text { change and take a leadership role in } \\
\text { promoting SD. }\end{array}$ & 7 & $\begin{array}{l}\text { Older designers remain stuck in } \\
\text { traditional practices, and do not see } \\
\text { the importance of SD. }\end{array}$ & 1 \\
\hline $\begin{array}{l}\text { Corporations are starting to address } \\
\text { SD issues. }\end{array}$ & 5 & SD is becoming a way of thinking. & 1 \\
\hline $\begin{array}{l}\text { Major clients are asking for } \\
\text { sustainable solutions. }\end{array}$ & 4 & & \\
\hline $\begin{array}{l}\text { Consumers are asking for it, and are } \\
\text { critical of companies with poor SD } \\
\text { practices. }\end{array}$ & 3 & & \\
\hline $\begin{array}{l}\text { There is global awareness, but little } \\
\text { action, perhaps because SD is hard } \\
\text { to manifest. }\end{array}$ & 3 & & \\
\hline $\begin{array}{l}\text { It is hard to include sustainable } \\
\text { practices when profit remains the } \\
\text { main driver. }\end{array}$ & 2 & & \\
\hline $\begin{array}{l}\text { We are bombarded with so much } \\
\text { information today it is hard to focus } \\
\text { on what is important. }\end{array}$ & 2 & & \\
\hline $\begin{array}{l}\text { Conferences typically feature some } \\
\text { talks on SD. }\end{array}$ & 2 & & \\
\hline
\end{tabular}

Question twelve asked participants, to their knowledge, how often professional designers considered SD in the projects they developed in industry (Table 27). About half said occasionally $(n=14)$, a little less than a third $(n=8)$ said frequently, and only a couple $(n=2)$ said always. A handful said rarely $(n=4)$, and about half $(n=14)$ said designers consider SD when choosing materials and production methods (Table 27). Some said the inclusion of sustainable practices was dependent on the willingness of the 
client $(n=6)$. A similar statement was the cost associated with sustainable options remained an obstacle $(n=3)$. Several said designers consider sustainability when they develop project strategy $(n=5)$, and that designers are inherently aware of SD throughout project lifecycle $(n=4)$-an observation best summed up by one participant who said SD had become a synonym for modern design. Another participant said the use of sustainable practices was very much dependent on what the designer learned in their design program.

Table 27

Consideration of SD in Professional Projects

\begin{tabular}{lll}
\hline Response & $\mathrm{n}$ & $\%$ \\
\hline Always & 2 & 6.7 \\
Frequently & 8 & 26.7 \\
Occasionally & 14 & 46.7 \\
Rarely & 4 & 13.3 \\
Never & 0 & 0.0 \\
Uncertain at this time & 2 & 6.7 \\
Total & 30 & 100.0 \\
\hline
\end{tabular}

Table 28

Examples of SD in Professional Projects

\begin{tabular}{lclc}
\hline Common & $\mathrm{n}$ & Unique & $\mathrm{n}$ \\
\hline $\begin{array}{l}\text { Choice of project materials and } \\
\text { production methods. }\end{array}$ & 14 & $\begin{array}{l}\text { A lot of lobbying in industry to use } \\
\text { sustainable practices. }\end{array}$ & 1 \\
$\begin{array}{l}\text { Depends on how willing the client is } \\
\text { to consider sustainable solutions. }\end{array}$ & 6 & $\begin{array}{l}\text { Adoption is dependent on perceived } \\
\text { value of SD. }\end{array}$ & 1 \\
$\begin{array}{l}\text { Designers consider SD when } \\
\text { developing the strategic direction of } \\
\text { a project. }\end{array}$ & 5 & $\begin{array}{l}\text { Depends on what a designer knows, } \\
\text { and what they learned at school. }\end{array}$ & 1 \\
$\begin{array}{l}\text { Designers are inherently aware of } \\
\text { SD throughout project lifecycle. }\end{array}$ & 4 & $\begin{array}{l}\text { SD has become a synonym for } \\
\text { modern design. }\end{array}$ & 1 \\
$\begin{array}{l}\text { Cost remains an obstacle to } \\
\text { including SD options. }\end{array}$ & 3 & $\begin{array}{l}\text { Some companies are devoted } \\
\text { entirely to SD. }\end{array}$ & 1 \\
\hline
\end{tabular}


Question thirteen asked participants if their institution referenced SD in their strategic plan (Table 29). Although participants were given the questionnaire beforehand, these responses were based on their knowledge at the time of the interview. A little more than two-thirds $(n=22)$ said SD was referenced in their institution strategic direction, as opposed to some $(n=5)$ who said they were not. A few $(n=3)$ were uncertain. When asked about other SD strategies or programs, a little over a third of participants $(n=12)$ said their institution had an office of sustainability or similar committee or professional. Roughly a third ( $n=11)$ said SD had been implemented campus-wide with initiatives such as recycling, use of metal cutlery in the cafeteria, and materials used in the construction of new buildings. Less than a third of participants $(n=7)$ said their institution had labs or programs focused specifically on SD. A couple $(n=2)$ said economic sustainability was the institution's priority. One participant said SD didn't appear in the first five pages of their institution's strategy, and must therefore not be very important. By contrast, another participant attributed the inclusion of SD in their curricula because it was featured so prominently in their institution's strategic plan. One participant said their institution was investigating how SD was addressed in different programs, and another said their strategy, under the quality of education section, discussed how universities and colleges could work together.

Table 29

Reference to SD in Institution Strategic Direction or Plan

\begin{tabular}{lll}
\hline Response & $\mathrm{n}$ & $\%$ \\
\hline Yes & 22 & 73.3 \\
No & 5 & 16.7 \\
Uncertain at this time & 3 & 10.0 \\
Total & 30 & 100.0 \\
\hline
\end{tabular}


Table 30

Institution Programs Focused on SD

\begin{tabular}{|c|c|c|c|}
\hline Common & $\mathrm{n}$ & Unique & $\mathrm{n}$ \\
\hline $\begin{array}{l}\text { Has an office, committee or } \\
\text { professional dedicated to } \\
\text { sustainability. }\end{array}$ & 12 & $\begin{array}{l}\text { SD does not appear in first } 5 \text { pages } \\
\text { of strategic document, so must not } \\
\text { be that important to institution. }\end{array}$ & 1 \\
\hline $\begin{array}{l}\text { Implemented campus-wide with } \\
\text { initiatives such as recycling, } \\
\text { reduction of plastic utensils, and use } \\
\text { of construction materials. }\end{array}$ & 11 & $\begin{array}{l}\text { Because SD has been featured } \\
\text { prominently in strategy, have been } \\
\text { conscious of including in curricula. }\end{array}$ & 1 \\
\hline $\begin{array}{l}\text { Institution has labs or programs } \\
\text { dedicated to sustainable design, } \\
\text { development and/or research. }\end{array}$ & 7 & $\begin{array}{l}\text { Institution does not mandate SD in } \\
\text { curricula, but they are investigating } \\
\text { how it has been addressed in } \\
\text { different programs. }\end{array}$ & 1 \\
\hline $\begin{array}{l}\text { Mostly focused on economic } \\
\text { sustainability of institution. }\end{array}$ & 2 & $\begin{array}{l}\text { Under quality of education section, } \\
\text { strategy discusses how colleges and } \\
\text { universities could work together. }\end{array}$ & 1 \\
\hline
\end{tabular}

The fourteenth question asked participants to what extent SD concepts were included in their curricula (Table 31$)$. Their response was positive. A handful $(n=5)$ said SD concepts were always included, roughly half $(n=14)$ said they were frequently included, and about a third $(n=9)$ reported they were occasionally included. Only a couple $(n=2)$ said SD concepts were rarely included. The follow-up question asked participants for examples of SD concepts in their curricula (Table 32). About two-thirds $(n=19)$ said SD was discussed in specific courses and projects, and a little over a third ( $n$ =12) said SD was baked into the entire program as a philosophy or set of core values-a theme that was perhaps best summed up by one respondent who said industrial design was synonymous with SD. About a third $(n=9)$ reported students had participated in related community projects, competitions, speaking events, and workshops. Less than a third $(n=7)$ of participants said their program had a specific course focused on SD. 
Table 31

Inclusion of SD Concepts in Design Program Curricula

\begin{tabular}{lll}
\hline Response & $\mathrm{n}$ & $\%$ \\
\hline Always included & 5 & 16.7 \\
Frequently included & 14 & 46.7 \\
Occasionally included & 9 & 30.0 \\
Rarely included & 2 & 6.7 \\
Never included & 0 & 0.0 \\
Total & 30 & 100.0 \\
\hline
\end{tabular}

Table 32

Examples of SD Concepts in Design Program Curricula

\begin{tabular}{llll}
\hline Common & $n$ & Unique & $n$
\end{tabular}

Discussed in specific courses and projects.

$\mathrm{SD}$ is baked into the program as an overarching philosophy or set of values.

Students participate in community 9 projects, competitions, speaking events, or workshops.

Course specifically dedicated to SD.
19 Industrial design is synonymous with SD.

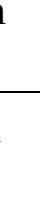


understanding of how to implement SD concepts into their strategies and outcomes, and a few said ( $n=3)$ SD had become fundamental to their thinking process, after having been applied to project outcomes. A couple of participants $(n=2)$ said graduates were successfully carrying SD over to their professional practice. There were several unique responses to this question as well. One participant said discussing global challenges and the technical methodologies of SD with design students was like pulling teeth. Another said some students were singing up for their program because of the inclusion of SD. One participant said students were very engaged with SD concepts when they were situated in real world contexts.

Table 33

Student Reaction to Studying SD

\begin{tabular}{lll}
\hline Response & $\mathrm{n}$ & $\%$ \\
\hline Positive & 24 & 80.0 \\
Mostly positive & 5 & 16.7 \\
Indifferent & 0 & 0.0 \\
Mostly negative & 0 & 0.0 \\
Negative & 0 & 0.0 \\
Uncertain at this time & 1 & 3.3 \\
Total & 30 & 100.0 \\
\hline
\end{tabular}


Table 34

Responses to Student Reaction to Studying SD

\begin{tabular}{|c|c|c|c|}
\hline Common & $\mathrm{n}$ & Unique & $\mathrm{n}$ \\
\hline $\begin{array}{l}\text { Comes naturally to the younger } \\
\text { generation, and they understand the } \\
\text { broader need for it. }\end{array}$ & 19 & $\begin{array}{l}\text { Discussing global challenges or } \\
\text { technical SD methods with design } \\
\text { students is like pulling teeth. }\end{array}$ & 1 \\
\hline $\begin{array}{l}\text { They are passionate about SD, } \\
\text { seeing themselves as change agents. }\end{array}$ & 7 & $\begin{array}{l}\text { Some students have registered in } \\
\text { the program because of the } \\
\text { inclusion of SD. }\end{array}$ & 1 \\
\hline $\begin{array}{l}\text { Need a better understanding of how } \\
\text { to implement SD into design strategy } \\
\text { and outcomes. }\end{array}$ & 5 & $\begin{array}{l}\text { They had no idea how impactful the } \\
\text { role of designer can be in applying } \\
\text { SD concepts. }\end{array}$ & 1 \\
\hline $\begin{array}{l}\text { Depends on previous exposure and } \\
\text { whether they live in urban or rural } \\
\text { neighbourhoods. }\end{array}$ & 3 & $\begin{array}{l}\text { Students are very engaged with } \\
\text { these concepts when they are } \\
\text { situated in real-world contexts. }\end{array}$ & 1 \\
\hline $\begin{array}{l}\text { Even if unsure at first, becomes } \\
\text { fundamental to their thinking } \\
\text { process once applied to outcomes. }\end{array}$ & 3 & $\begin{array}{l}\text { Some have become overly sensitive } \\
\text { to } \mathrm{SD} \text {, and need to be reminded to } \\
\text { think on a bigger scale. }\end{array}$ & 1 \\
\hline $\begin{array}{l}\text { Graduates are successfully carrying } \\
\text { SD over to their professional } \\
\text { practice. }\end{array}$ & 2 & & \\
\hline
\end{tabular}




\section{Discussion}

\subsection{Design School Perspectives of the SDGs}

Findings suggest the SDGs remain relatively unknown to industrial and graphic design programs. Out of 30 participants, only a third were aware of the SDGs prior to this study, and there was mixed reaction about how effective the UN had been at raising awareness for the SDGs (Figure 4). For example, one participant said they had been working in the field for some time, but had never heard of them. They did, however, see SD emerging as a worldwide challenge, and understood the role of design and design practitioners in overcoming SD challenges. There was some agreement that the SDGs addressed known SD issues, although some questioned how they were actionable locally.
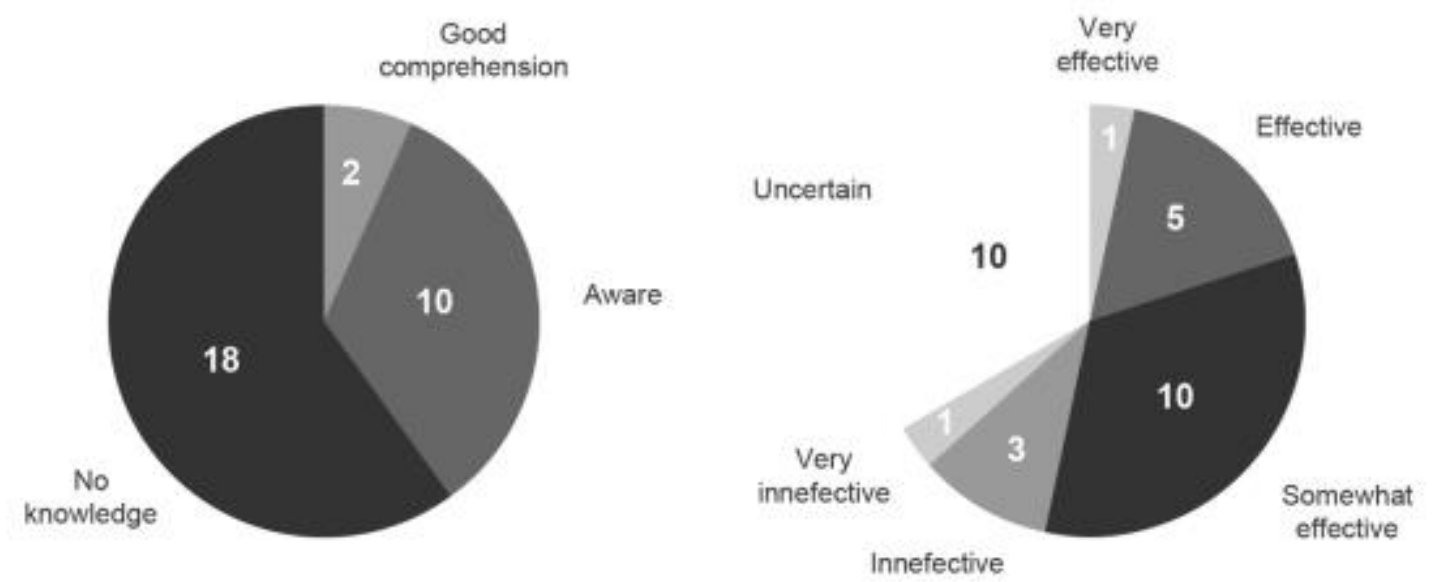

Figure 4. Awareness of SDGs (left) and their effectiveness as an SD initiative (right).

Of the fifty-eight program descriptions, less than one-third mentioned SD and the role of design in addressing social, cultural and economic issues, and none of them mentioned the SDGs specifically (Figure 5). Arguably there are more important topics to discuss, such as the kinds of theories and applied skills taught, and career prospects of the 
profession, both of which are mentioned quite frequently. But by taking these descriptions at face value, to gain an understanding of how design schools position themselves, this study suggests most Canadian industrial and graphic design programs have yet to align themselves with global SD objectives.

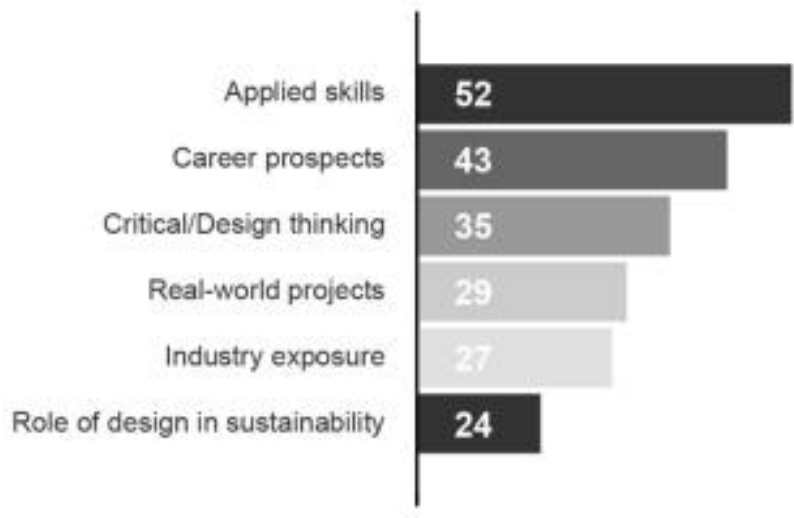

Figure 5. Emerging themes from fifty-eight program descriptions by mention.

\subsection{The SDGs and Design School Curricula}

This study shows the SDGs identify key SD issues and would support critical thinking activities, or as a reference when considering SD in curricula, but as a framework for teaching SD in design, they remain too strategic and broad. The major challenge of working the SDGs into curricula would be faculty buy-in, and the time and resources to introduce new content to already dense curricula. Most design schools have not included the SDGs in their curricula, however, we found faculty and students were aware of SD, which had already been included in programs as an overarching philosophy, or included in specific projects and courses (Figure 6). One participant commented that $\mathrm{SD}$ is a synonym for modern design. The inclusion of the SDGs may therefore not be so much a matter of reworking the curricula, as simply making a few adjustments. 

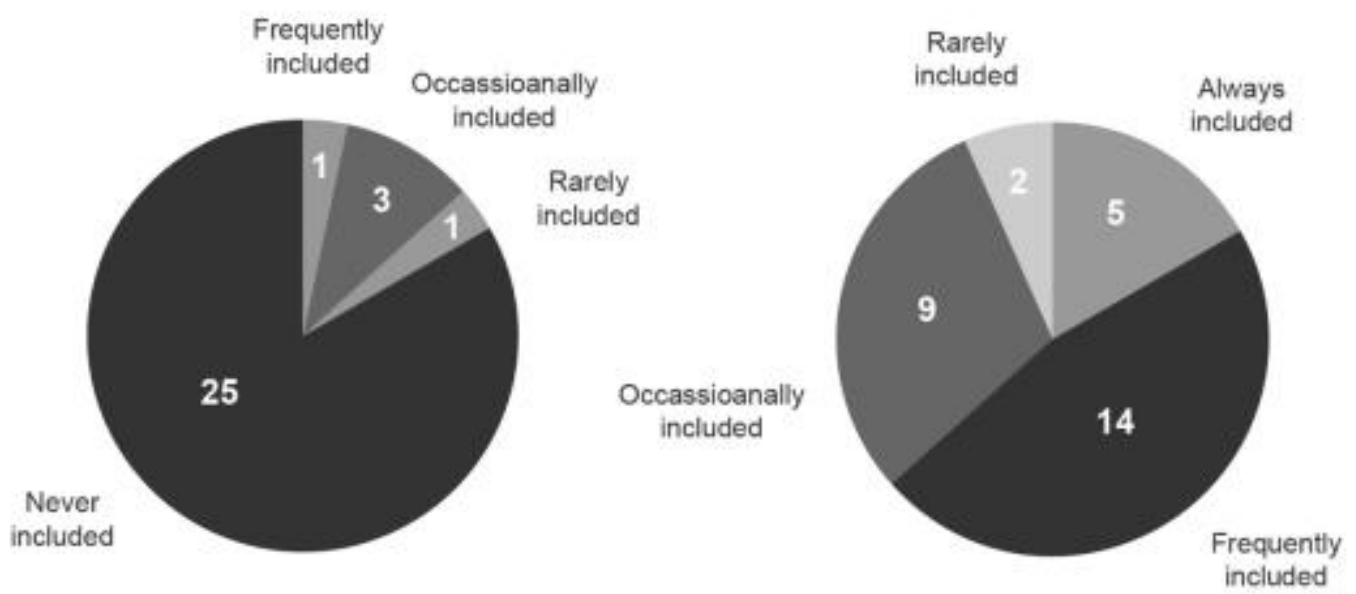

Figure 6. Inclusion of SDGs (left) and SD (right) in design program curricula.

There would be little resistance from students to the SDGs. Coordinators said SD came naturally to their students - that they understood the broader need for it (Figure 7). Students have reacted positively to the inclusion of SD in past projects, and see themselves as agents of change. What coordinators need is guidance on how to implement the SDGs into their curricula, as in present form they remain broad and strategic. As some suggested, teaching resources and materials would be useful.

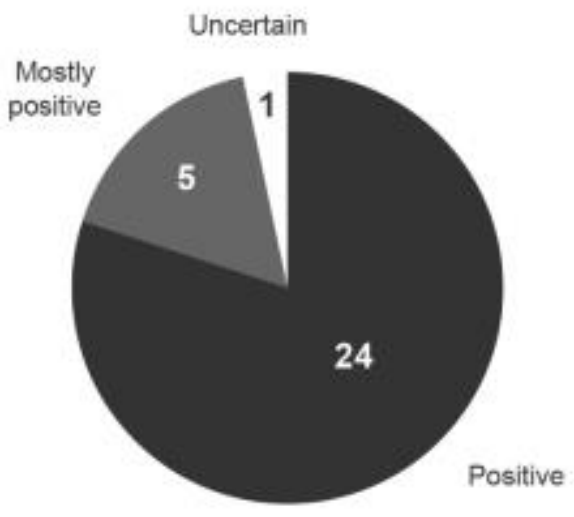

Figure 7. Student reaction to studying SD. 


\subsection{University and College Strategy and the SDGs}

Most institutions have referenced SD concepts in their strategic plan, and many have an office of sustainability (or similar), campus wide initiatives such as recycling and construction materials, and programs or labs dedicated to research. However, according to our participants, none of their institutions had referenced the SDGs in their strategic plan (Figure 8).
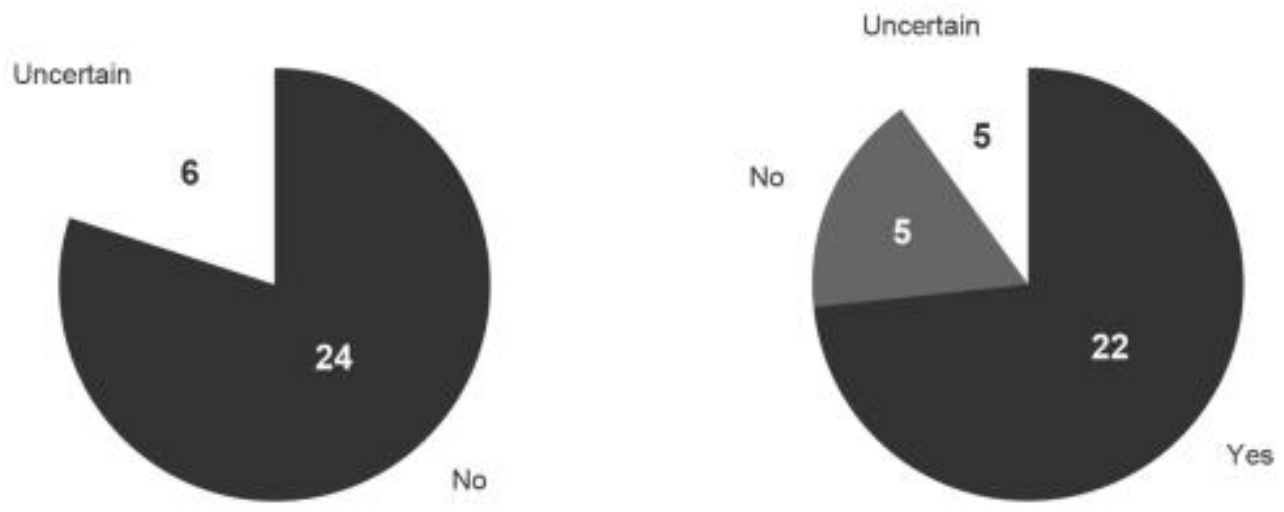

Figure 8. Reference to SDGs (left) and SD (right) in strategic plan.

Findings from our study did not support those of the literature review. The IAU, which has 14 members in Canada, found $34 \%$ of institutions had included SD in their institution strategy, and the Vaughter et al. (2015) study of 220 Canadian institutions found $50 \%$ had done so. According to our study, $73 \%$ of institutions had included SD in their strategic plan, a somewhat higher percentage than the other studies. The IAU study also suggested most higher education institutions were aware of the SDGs $(70 \%$ according to their findings), yet our findings reveal Canadian institutions have yet to include the SDGs in their strategic plans. At the time of this study, the SDGs were 
relatively new - it is possible Canadian institutions need more time to react to them.

Our study indicates most programs operate independently of their institution. Only one participant said they had considered SD in their curriculum because of their institution's inclusion of SD in their strategic plan, and another said their institution was in the process of examining how SD was being addressed in different programs. These were the only two examples of a program aligning with the strategic SD initiatives of their institution. These findings support the Lozano et al. $(2013 ; 2015)$ criticism of higher education being sluggish in applying SD across all programs.

\subsection{SDGs and the Professional Design Community}

The professional design community has been discussing SD, but has little awareness of the SDGs (Figure 9). Clients and corporations are starting to ask for sustainable solutions, perhaps in response to a public becoming aware of planetary problems and the need for SD, as well as consumers seeking sustainable products and holding companies with poor attitudes towards SD accountable. As one participant commented, SD is becoming a way of thinking.
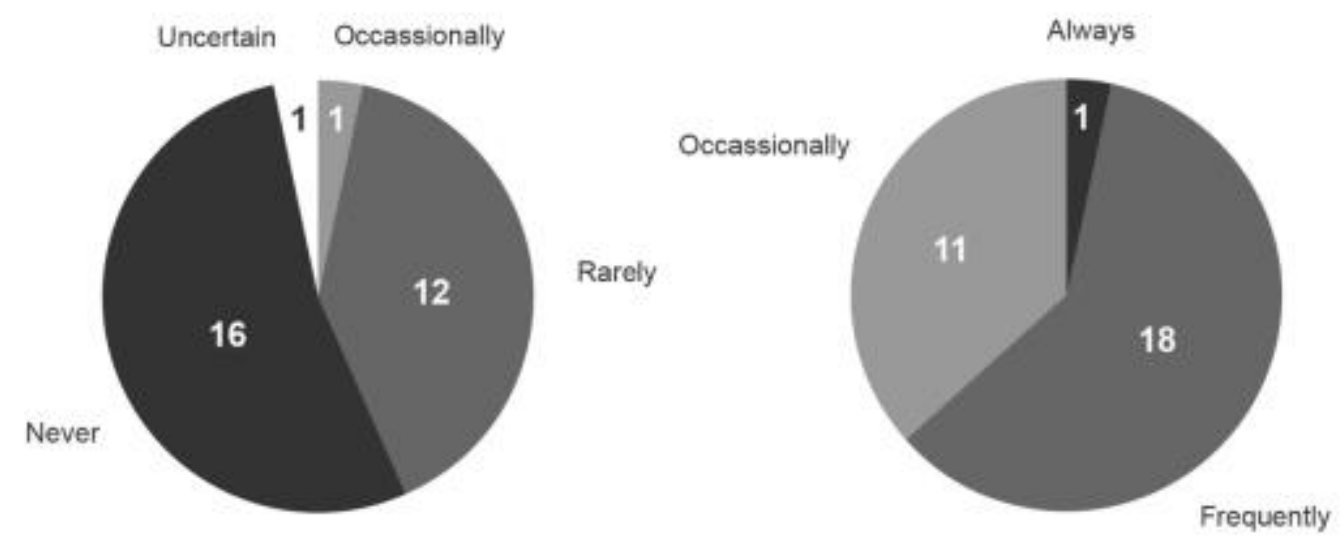

Figure 9. Discussion related to SDGs (left) and SD (right) in design community. 
According to participants, designers are positioned to promote SD, but can be limited by budgets and a client's perceived value of SD when developing project strategy. They are inherently aware of SD when working on projects, and make decisions on materials and production methods accordingly (Figure 10). Design and SD are related, but the use of sustainable practices will be dependent on what a designer knows and what they learn at school.

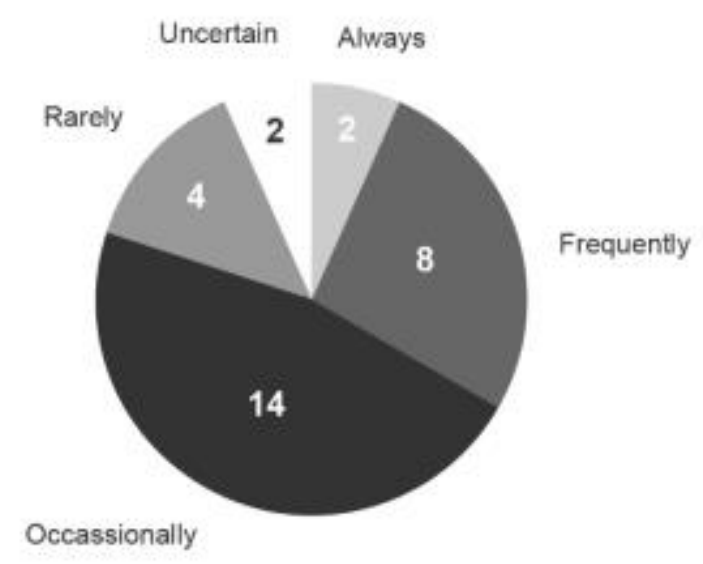

Figure 10. Consideration for SD in industry projects.

\subsection{Future Research}

Globally the SDGs have some traction. The WDO references the SDGs in their strategy and vision, and have been actively promoting the role of young designers in overcoming SD challenges. The fact Canadian industrial design programs have not included the SDGs in their curricula might suggest WDO communication has not been effective at connecting with regional design educators. Awareness of the global design associations might be an issue. There were thirteen industrial design schools in the sample and only three participants identified as members of the WDO. Even if ICOD 
were to include the SDGs in their strategy, only two participants identified as affiliated from a sample of nineteen graphic design programs. This study questions the impact of global design associations in raising awareness for the SDGs if they are hardly referenced by design programs across Canada.

Future research might examine the relationship between global and regional design associations. Global design associations might have better success at raising awareness for the SDGs if they were to partner with their regional counterpart. About half of the programs in our study were affiliated with the RGD, and more than a third the GDC. Two programs were affiliated with ACIDO, and in Québec programs affiliated with ADIQ and SDGQ. If the WDO and ICOD were to connect with their regional counterparts and help them to align their SD strategies and programs with the SDGs, these global associations might open a channel to communicate with design programs, as well as professional design communities. This might create a network, as design programs become aware of the SDGs from their affiliated regional design association, and through interactions with their professional community (and vice versa). If design schools were then more vocal about their SD activities and the SDGs in their program descriptions, they might help raise awareness within their own program, institution, and other programs (Figure 11). 


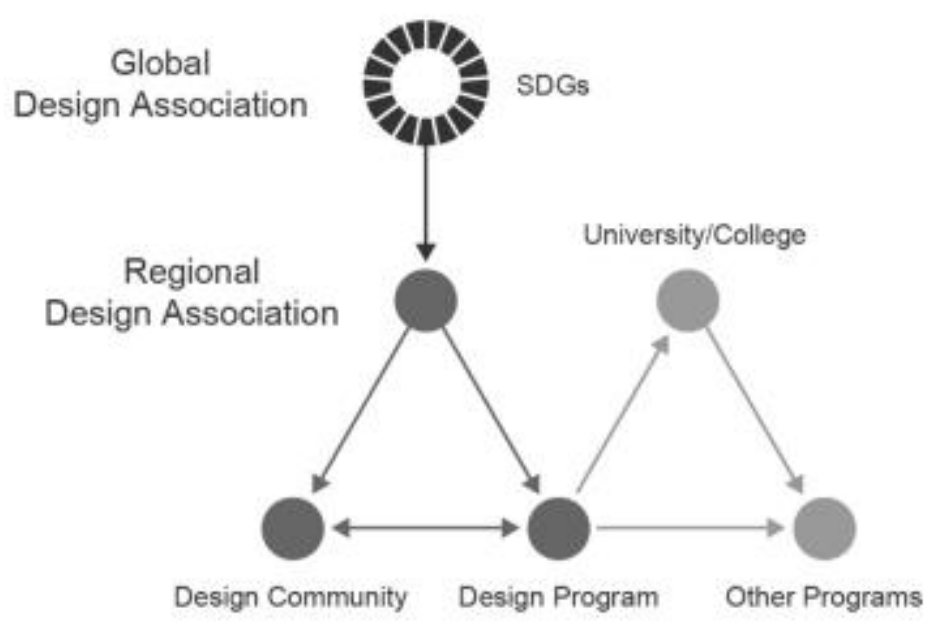

Figure 11. Network between design associations, community, and program.

What remains unclear is how to include the SDGs in design school curricula, or how they align with faculty research. Future research might examine the intersection of these three themes to develop a toolkit for the inclusion of SDGs in design school curricula (Figure 12). Researchers might start with an examination of existing ESD toolkits for higher education, such as the one developed by McKeown et al. (2002), and connect with design programs who have already embedded the SDGs in their curricula.

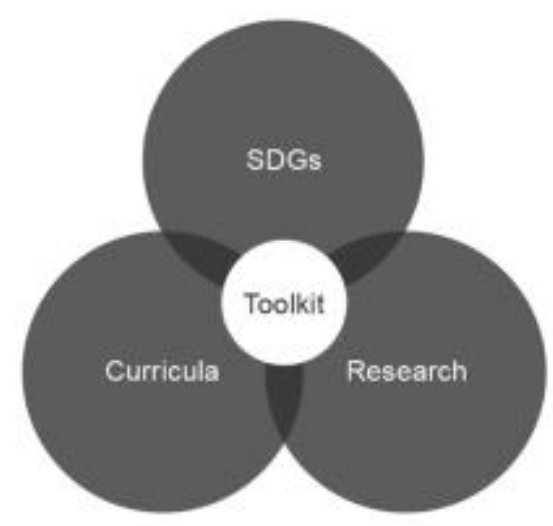

Figure 12. Proposed toolkit for introducing SDGs into design program curricula. 


\section{Conclusion}

Human activity and resource usage has started to surpass finite planetary limits. $\mathrm{SD}$ is an approach to human growth that reconciles a growing economy with the environment and society (Sachs, 2015). It is both a field of study and a philosophy, and it is riddled with challenges. Achieving SD will require a global shift in thinking, and a new kind of problem solver.

All one hundred and ninety-three members of the UN General Assembly have agreed to the SDGs (UN, 2015b). We conducted this study to examine how Canadian industrial and graphic design programs have applied the SDGs to their curricula, and whether the SDGs had been adopted by higher education institutions and the professional design community. Findings revealed the SDGs are all but unknown to industrial and graphic design programs and their institutions across Canada, and have gained little traction in the professional design community. However, most design programs in our study have already included SD as either a theme across all curricula, or in individual courses or projects, and their respective institutions have already referenced SD themes in their strategic plans. Furthermore, our research has shown SD is frequently discussed in the professional design community. These findings were not surprising considering the SDGs were launched in 2015, and we were encouraged to learn there is already momentum towards the inclusion of SD in Canadian design program curricula.

Global design associations have had little success in increasing the awareness of the SDGs in Canadian industrial and graphic design programs, perhaps due to these associations remaining relatively unknown to regional design educators. Regional design associations have yet to align their strategies or programs with the SDGs, but they do 
promote SD and are well known to design programs. Future research might examine how global design associations could partner with their regional counterparts to create a network with affiliated design programs, and regional design communities.

Findings did not identify a significant barrier to embedding the SDGs in design school curricula. Design program coordinators discussed the role of design in overcoming SD challenges, and students were naturally inclined towards sustainable solutions. For some it would be a matter of adjusting existing content, and for others expanding the SDGs as a theme across the program curricula. However, we found the SDGs remained too broad and strategic, and there was uncertainty as to how they applied to learning design. Future research might explore the development of a toolkit that balances the SDGs, faculty research, and design school curricula.

Design schools play a role in educating the next generation of thinkersindividuals with the potential to overcome the SD challenges outlined by the SDGs. As Daly (2007, p. 12) suggested, "developing an economy that can be sustained within the finite biosphere will require new ways of thinking”. By creating a stronger network between design associations, professional communities, and design schools, and by developing a toolkit for design educators, we can provide young designers with the skills to build a sustainable future. 


\section{$7 \quad$ Limitations}

This study was limited to three- and four-year industrial and graphic design programs in Canada. There are similar programs around the world, as well as one- and two-year programs in Canada that may provide additional data. Architecture and interior design programs (among others) were not included, and might also be of value.

The findings and insights from this study were based on participants' knowledge of SD and the SDGs at the time they were interviewed. The participation of faculty and students in future research may provide additional insight.

This study takes the SDGs at face value, as a proposed solution to SD challenges. The purpose of our research was to explore whether Canadian design schools were aware of the SDGs, and if they had included them in their curricula. We did not explore alternate approaches to SD, or arguments against the SDGs.

Students from industrial and graphic design programs learn user-centered methodologies for ideating, prototyping, and testing concepts. We feel the findings and recommendations in this study apply to both industrial and graphic design programs, however, future research into an SDGs toolkit for design educators may be sensitive to the differences between design disciplines. 


\section{$8 \quad$ References}

Association of Canadian Industrial Designers. (2017). Industrial design. Retrieved from http://www.designcanada.org/what-is-ID.html

Association de designers industriels du Québec. (2017). Étudier en design industriel. Retrieved from https://adiq.qc.ca/etudier-en-design-industriel

Association of Chartered Industrial Designers of Ontario. (2017). Industrial design. Retrieved from http://acido.info/wordpress/why-industrial-design Association of Registered Graphic Designers. (2017). Celebrate the power of design. Retrieved from https://www.rgd.ca/events-and-programs/so-good-awards Barney, G. O. (1980). The global 2000 report to the President: Entering the twenty-first century. Washington, DC: U.S. Government Printing Office.

Beall, J. (2013). Post 2015 agenda: Why the UN must include higher education. British Council. Retrieved from https://www.britishcouncil.org/voices-magazine/unincludes-higher-education-post-2015-development

Bernard, H. R. (2006). Research methods in anthropology: Qualitative and quantitative approaches. Lanham, MD: AltaMira Press.

Beveridge, D., McKenzie, M., Vaughter, P., \& Wright, T. (2015). Sustainability in Canadian post-secondary institutions. International Journal of Sustainability in Higher Education, 16(5), 611-638.

Caradonna, J. L. (2014). Sustainability: A history [Kindle version]. New York, NY: Oxford University Press. 
Council of Ministers of Education Canada. (2012). Education for sustainable development in Canadian faculties of education. Retrieved from https://www.iisd.org/pdf/2013/esd_canadian_faculties.pdf

Costanza, R., Graumlich, L., Steffen, W., Crumley, C., Dearing, J., Hibbard, K., ... Schimel, D. (2007). Sustainability or collapse: What can we learn from integrating the history of humans and the rest of nature? Swedish Academy of Sciences, 36(7), 522-527.

Daly, H. E. (2007). Ecological economics and sustainable development: Selected essays of Herman Daly. Advances in Ecological Economics. Cheltenham, UK: Edward Elgar Publishing Ltd.

Desrochers, P., \& Hoffbauer, C. (2009). The post war intellectual roots of the population bomb: Fairfield Osborn's “Our Plundered Planet” and William Vogt's "Road to Survival" in retrospect. The Electronic Journal of Sustainable Development, 1(3), 73-97.

Ehrlich, P. R. (1968) The population bomb. New York: Ballantine Books.

Grober, U. (2012). Sustainability: A cultural history [Kindle version]. Devon UK: Green Books.

Society of Graphic Designers of Canada. (2017). About sustainability. Retrieved from https://www.gdc.net/about/sustainability/about-sustainability

Glaser, B. G., \& Strauss, A. L. (1967). The discovery of grounded theory: Strategies for qualitative research. Chicago: Aldine Pub. Co.

Harding, R. (2006). Ecologically sustainable development: Origins, implementation and challenges. Desalination, 187(1-3), 229-239. 
International Council of Design. (2017). Globalization and design: Midterm reflections. Retrieved from http://www.ico-d.org/2017/01/10/globalisation-and-design-midterm-reflections.php

International Union for Conservation of Nature and Natural Resources. (1980). World conservation strategy: Living resource conservation for sustainable development. Retrieved from https://portals.iucn.org/library/efiles/documents/wcs-004.pdf International Association of Universities. (2016). IAU global survey on HESD. Retrieved from https://www.iau-hesd.net/sites/default/files/documents/iau-hesd-survey2016.pdf

Intergovernmental Panel on Climate Change. (2014). Climate change 2014: Synthesis report. Retrieved from https://www.ipcc.ch/pdf/assessmentreport/ar5/syr/AR5_SYR_FINAL_SPM.pdf

Lozano, R., Lukman, R., Lozano, F. J., Huisingh, D., \& Lambrechts, W. (2013). Declarations for sustainability in higher education: Becoming better leaders, through addressing the university system. Journal of Cleaner Production, $48,10-19$.

Lozano, R., Ceulemans, K., Alonso-Almeida, M., Huisingh, D., Lozano, F. J., Waas, T., ... Hugé, J. (2015). A review of commitment and implementation of sustainable development in higher education: Results from a worldwide survey. Journal of Cleaner Production, 108, 1-18.

MacGregor, K. (2010). GLOBAL: Higher education a driver of the MDG. University World News. Retrieved from http://www.universityworldnews.com/article.php?story=20100501081126465 
Martin, R. (2009). Design of business: Why design thinking is the next competitive advantage. Brighton, Massachusetts: Harvard Business Press.

McKeown, R., Hopkins, C. A., Rizzi, R., \& Chrystalbride, M. (2002). Education for sustainable development toolkit. Knoxville, TN: University of Tennessee.

Meadows, D. H., Meadows, D. H., Randers, J., \& Behrens III, W. W. (1972). The limits to growth. New York: Universe Books.

Sachs, J. D. (2015). The age of sustainable development [Kindle version]. New York: Columbia University Press.

Selman, P. H. (1985). Responding to the World Conservation Strategy. The Environmentalist, 5(4), 263-268.

Schön, D. A. (1987). Educating the reflective practitioner [Kindle version]. San Francisco, California: Jossey-Bass. Retrieved from amazon.com

Simon, K., \& Haertle, J. (2014). Rio + 20 higher education sustainability initiative (HESI) commitments: A review of progress. Retrieved from http://www.unprme.org/resource-docs/HESIProgressReportOct2014FINAL.pdf Société design designers graphiques du Québec. (2017). Code de déontologie. Retrieved from http://www.SDGsq.ca/SDGsq/position/deontologie

Steffen, W., Richardson, K., Rockström, J., Cornell, S., Fetzer, I., Bennett, E., Carpenter, S. (2015). Planetary boundaries: Guiding human development on a changing planet. Science, 348(6240), 1217.

United Nations. (1972). Report of the United Nations conference on the human environment. Retrieved from: http://www.un-documents.net/aconf48-14r1.pdf 
United Nations. (2015a). The millennium development goals report. Retrieved from: http://www.un.org/millenniumgoals/reports.shtml

United Nations. (2015b). Transforming our world: The 2030 agenda for sustainable development. United Nations General Assembly. Retrieved from http://www.un.org/ga/search/view_doc.asp?symbol=A/RES/70/1\&Lang=E

United Nations. (2017c). Communications materials. Retrieved from http://www.un.org/sustainabledevelopment/news/communications-material United Nations Department of Economic and Social Affairs. (2015). The world population prospects: 2015 revision. Retrieved from http://www.un.org/en/development/desa/publications/world-population-prospects2015-revision.html

United Nations Educational, Scientific and Cultural Organization. (2014). Shaping the future we want. Retrieved from: http://unesdoc.unesco.org/images/0023/002303/230302e.pdf

United Nations Educational, Scientific and Cultural Organization. (2017). UN decade of ESD. Retrieved from http://en.unesco.org/themes/education-sustainabledevelopment/what-is-esd/un-decade-of-esd

Vaughter, P., Wright, T., \& Herbert, Y. (2015). 50 shades of green: An examination of sustainability policy on Canadian campuses. Canadian Journal of Higher Education, 45(4), 81-100.

World Commission on Environment and Development. (1987). Our common future. Retrieved from http://www.un.org/ga/search/view_doc.asp?symbol=A/42/427\&Lang=E 
World Design Organization. (2017a). Vision and mission. Retrieved from http://wdo.org/about/vision-mission/

World Design Organization. (2017b). Stories. Retrieved from http://wdo.org/stories

World Design Organization. (2017c). Youth and design: A powerful combination. Retrieved from http://wdo.org/programmes/widd/widd2016/youth-and-design-apowerful-combination 


\section{$9 \quad$ Appendices}

\section{Appendix A Ethics Clearance}

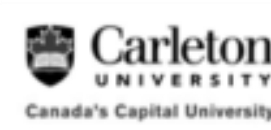

Pesearch Compliance Ottice 511 Tory I 1125 Colonet By Drive

I Ottawa, Ontario K1S 586

613-520-2600 Ext: 4085

ethics@carleton.c8

\section{CERTIFICATION OF INSTITUTIONAL ETHICS CLEARANCE}

Ethics clearance for the following research has been cleared by the Carleton University Pesearch Ethics Board-B (CUREB-B) at Carleton University. CUAEB-B is constituled and operates in compliance with the Tri-Council Policy Statement: Ethical Conduct for Research involing Humans (TCPS2).

Ethics Protocol Clearance ID: Project 104849

Faculty Supervisor: Dr. Thomas Garvey

Co-Inwestigator(s) (It applicable): Jed Looker (Student Research: Master's Student)

Study Title: "Canadian Design School Curriculum and the United Nations Sustainable Development Goals."

Funding Source (If applicable):

Effective: July 21, 2016

Expires: July 31, 2017

\section{Restrictions:}

This certification is subject to the following conditions:

1. Clearance is granted only for the research and purposes described in the application.

2. Ary modification to the approved research must be submitted to CUREB-B. All changes must be approved prior to the continuance of the research.

3. An Annual Application for the renewal of ethics clearance must be submitted and cleared by the above date. Failure to submit the Annual Status Report will result in the closure of the file. If funding is associated, funds will be frozen.

4. A closure request must be sent to CUREB-B when the research is complete or terminated.

5. Should amy participant sutter adversely from their participation in the project you are required to report the matter to CUREB-B.

6. It is the responsibility of the student to notify their supervisor of any adverse events, changes to their application, of requests to renew/close the protocol.

7. Failure to conduct the research in accordance with the principles of the Tri-Council Policy Statement: Ethical Conduct for Research imaiving Humans andedition and the Carleton University Policies and Procedures for the Ethical Conduct of Research may result in the suspension or termination of the research project.

Please email the Ethics Coordinators at ethicswearleton ca if you have any questions If a researcher requires a

Please email the Ethics Coordinators at ethicsiecarleton.ca if you have amy questions. If a researcher requires a certificate with a signature, they may contact ethics@carleton.ca to have one generated.

CLEARED BY:

Shelley Brown, PhD, Chair, CUREB-B
Date:

July 21, 2016 


\section{Appendix B Invitation to Participate}

CUREB Clearance N104849

\section{Invitation to Participate Email}

Subject: Invitation to Participate in Design School Curricula Study

Hello [Person Name],

My name is Jed Looker, and I am a Master of Design student with the School of Industrial Design at Carleton University, under the supervision of Professor Thomas Garvey, PhD. As part of my thesis I am conducting a study to investigate the relationship between the United Nations Sustainable Develop Goals (SDGs) and 3 to 4-year post-secondary (university, college, and CEGEP) design school curricula in Canada. The goal of this study is to identify to what degree the SDGs are reflected in Canadian design school curricula.

For my study I will be conducting a 20-30 minute in-person or telephone interview (depending on location and availability) with university, college, and CEGEP design school coordinatorseducators who have experience teaching and developing curricula for design programs.

This study has been reviewed and cleared by the Carleton University Research Ethics Board-B (Protocol \#104849).

Would you be interested in participating in my study? If so, kindly reply to this email, or contact me at the coordinates below. If you are not the coordinator of the [Name] program, please feel free to forward this email to the appropriate individual.

Thanks for your time,

Researcher Contact Information

Jed Looker

School of Industrial Design

Carleton University

jed.looker@carleton.ca

Supervisor Contact Information

Thomas Garvey

School of Industrial Design

Carleton University

+16135202600 ext. 5674

thomas.garvey@carleton.ca 
Annexe 1 - Courriel d'invitation à participer à une étude

Objet : Invitation à participer à une étude sur les programmes d'écoles de design

[Madame Ou Monsieur],

Mon nom est Jed Looker. Je suis étudiant en maîtrise en design à l'École de design industriel de l'Université Carleton, sous la supervision du professeur Thomas Garvey (doctorat). Dans le cadre de ma thèse, je dirige une étude sur le lien existant entre les Objectifs de développement durable $(O D D)$ des Nations Unies et les programmes de trois à quatre ans d'écoles de design (université, collège et CEGEP) au Canada. L'objectif est d'évaluer dans quelle mesure les ODD sont pris en compte dans les programmes des écoles de design au pays.

Dans le cadre de cette étude, je compte réaliser un entretien téléphonique ou en personne (selon le lieu et la disponibilité) de 20 à 30 minutes avec des coordinateurs d'écoles de design d'universités, de collèges et de CEGEP - des enseignants ayant de l'expérience dans l'élaboration et l'enseignement de programmes de design.

L'étude a été examinée et autorisée par le Carleton University Research Ethics Board-B (Protocole $n^{\circ}$ 104849).

Êtes-vous intéressé(e) à participer à cette étude? Si oui, veuillez répondre au présent courriel ou communiquer directement avec moi (coordonnées ci-dessous). Si vous ne coordonnez pas le programme [Nom], n'hésitez pas à faire suivre le présent courriel à la personne chargée de sa coordination.

Merci de consacrer du temps à cette étude

Coordonnées du chercheur

Jed Looker

École de design industriel

Université Carleton

jed.looker@carleton.ca

Coordonnées du superviseur

Thomas Garvey

École de design industriel

Université Carleton

+1 613-520-2600, poste 5674

thomas.garvey@carleton.ca 


\title{
Appendix C Follow-up Email
}

CUREB-B Clearance N104849

\author{
Follow-up Email
}

Excellent.

How does [ Date and Time ] sound for a phone interview? If there is another time that would be more convenient, let me know and l'll schedule you in.

I will call you at 000-000-0000. If there is another phone number that would be more convenient, let me know and I'll use that one instead.

Please find attached the informed consent form. Kindly complete and email back to me before the scheduled interview date.

Also attached are the interview questions. This document is for preview purposes only, and does not need to be completed before the phone interview.

To learn more about the United Nations Sustainable Development Goals (SDGs), please see:

Sustainable Development Goals: 17 Goals to Transform Our World

http://www,un.org/sustainabledevelopment/

The Global Goals for Sustainable Development

http://www.globalgoals.org/

Sustainable Development Knowledge Platform

https://sustainabledevelopment.un.org/

Thanks,

Jed Looker

School of Industrial Design

Carleton University

jed.looker@carleton.ca 
Suivi email

Excellent.

Êtes vous disponible le [ Date et l'heure ] pur une entrevue téléphonique?

Je vais vous appeler a 000-000-0000. S'il ya un autre numéro de téléphone qui serait plus commode, laissez-moi savoir et je vais utiliser celui-là à la place.

Les questions d'entrevue et le consentement éclaré sont jointes ci-dessous. S'il vous plait remplir le consentement éclaré avant notre entretien.

Les questions d'entrevue sont également jointes. Ce document est à titre d'aperçu uniquement et ne doit pas être rempli avant l'entretien téléphonique.

Vous pouvez aussi rechercher le thème du mon étude avec les liens suivants:

Objectifs de développement durable

http://www.un.org/sustainabledevelopment/fr/

Objectifs Mondiaux

http://www.globalgoals,org/fr/

Connaissance de développement durable https://sustainabledevelopment.un.org/

Merci,

Jed Looker

École de design industriel

Université Carleton

jed.looker@carleton.ca

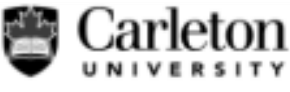

Canada's Capital University 


\section{Appendix D Informed Consent Form}

CUREB-B Clearance 104849

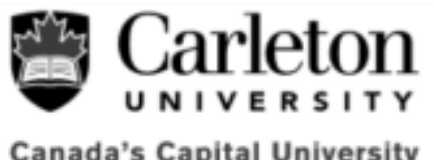

Informed Consent Form

Title: Design School Curricula Study

Date of Ethics Clearance: July 15, 2016

Ethics Clearance for the Collection of Data Expires: July 31, 2017

I__ choose to participate in a study on design school curricula. This study aims to investigate the relationship between the United Nations Sustainable Develop Goals and 3 to 4 -year post-secondary (university, college, and CEGEP) design school curricula in Canada. The researcher for this study is Jed Looker in the School of Industrial Design. He is working under the supervision of Professor Thomas Garvey, PhD, in the School of Industrial Design.

This study will conduct a 20-30 minute in-person or telephone interview (depending on location and availability) with university, college, and CEGEP design school coordinators.

With your consent interviews will be audio-recorded. As this study will be asking you questions related to your professional employment, there are potential professional risks to you if your statements are critical to your employer. While this risk is expected to be minimal, this study will take precautions to protect your identity.

Information collected will be digitally encrypted, confidential, and anonymously coded for research analysis and publication. Phone interviews will be audio-recorded using an iOS app called TapeACall. As per the TapeACall privacy policy, recorded audio is privately stored on their encrypted servers for 1 year, after which it is removed permanently. Recorded audio is also removed permanently when deleted by customer. Approximately one day after the phone interview all recorded audio will be downloaded to a password-encrypted MacBookPro, and permanently deleted from TapeACall servers. TapeACall is located in the United States, and subject to American laws. 
In-person interviews will be recorded using an iOS app called Awesome Voice Recorder. Recorded audio from in-person interviews will be stored on a password-encrypted iPhone before being transferred via password-encrypted Wi-Fi to a password-encrypted MacBook Pro. All recorded audio will be backed-up daily to a password-encrypted USB Flash Drive, and stored in a locked cabinet at Carleton University.

Only researcher and supervisor will have access to the research data and the coding file linking your personal information to the research data. No personal identifiers will be included in published literature. Upon study completion, the coding file, audio-recorded interviews, and all research data will be kept for 5 years and may be used for future research on the same topic. After five years, all research data will be securely destroyed. Hard copies of research data (including USB Flash Drives) will be kept in a locked cabinet at Carleton University.

You are under no obligation to answer any questions, and may withdraw from the study at any time, after which your personal information and collected research data will be destroyed.

If you would like a copy of the published study, you are invited to contact the researcher to request an electronic copy.

This study has been reviewed and cleared by the Carleton University Research Ethics Board-B (Protocol \#104849). Should you have questions or concerns related to your involvement in this research, please contact:

\section{CUREB Contact Information}

Shelley Brown, Chair (CUREB-B)

Andy Adler, Vice-Chair

Carleton University Research Ethics Board

Carleton University

511 Tory

1125 Colonel By Drive

Ottawa, ON K1S 586

613-520-2600 ext. 4085

ethics@carleton.ca

Researcher Contact Information

Supervisor Contact Information

Jed Looker

Thomas Garvey

School of Industrial Design

Carleton University

School of Industrial Design

Carleton University

+16135202600 ext. 5674

jed.looker@carleton.ca

thomas.garvey@carleton.ca 
CUREB-B Clearance $\# 104849$

Do you agree to participate in this study?

$\square$ Yes $\square$ No

Do you agree to be audio recorded?

$\square$ Yes $\square$ No

Signature of participant

Date

Signature of researcher

Date

This document has been printed on one side of a single sheet of paper.

3 of 3

Please retain a copy of this document for your records. 


\section{Carleton \\ U N I V E R I T Y \\ Canada's Capital University}

\section{Formulaire de consentement éclairé}

Titre : Étude sur les programmes d'écoles de design

Date de Pautorisation éthique : 15 juillet 2016

Date d'expiration de Pautorisation éthique concernant la collecte de données : 31 juillet 2017

Je soussigné(e)، décide de participer à l'étude sur les programmes d'écoles de design. Celle-ci a pour but d'étudier le lien entre les Objectifs de développement durable des Nations Unies et les programmes postsecondaires de trois à quatre ans dispensés dans les écoles de design au Canada. Chercheur à l'École de design industriel de l'Université Carlton, Jed Looker est responsable de l'étude. II travaille sous la supervision de Thomas Garvey, professeur (doctorat) à l'École de design industriel.

L'étude consiste à réaliser un entretien téléphonique ou en personne (selon le lieu et la disponibilité) de 20 à 30 minutes avec des coordinateurs d'écoles de design d'universités, de collèges et de CEGEP.

Avec votre consentement, l'entretien sera enregistré (audio). Étant donné que l'étude consiste à poser des questions liées à votre activité professionnelle, vos réponses pourraient comporter des risques sur le plan professionnel, en particulier si elles contiennent des critiques concernant votre employeur. Bien que ces risques soient minimes, des précautions seront prises pour protéger votre identité.

Les renseignements obtenus seront encodés numériquement, gardés confidentiellement et codés de façon à préserver l'anonymat dans toute analyse de recherche et toute publication. Les entretiens téléphoniques seront enregistrés (audio) au moyen de l'application iOS : TapeCall. Conformément à sa politique de confidentialité, TapeCall stocke les enregistrements sonores d'une manière confidentielle sur ses serveurs encodés pendant un an. Après ce délai, l'enregistrement sonore est supprimé définitivement. II est aussi détruit définitivement lorsqu'il est supprimé par le client. Environ un jour après l'entretien téléphonique, tout l'enregistrement sera transféré dans un MacBook Pro protégé par un mot de passe et 
supprimé définitivement dans les serveurs de TapelCall. Tapecall est installée aux ÉtatsUnis et assujettie aux lois américaines.

Les entretiens en personne seront enregistrés au moyen d'une application iOS : Voice Recorder. Le contenu audio de l'entretien sera sauvegardé dans un iPhone protégé par un mot de passe avant d'être transféré, via un réseau Wi-Fi protégé par un mot de passe, dans un MacBook Pro protégé aussi par un mot de passe. Par mesure de sécurité supplémentaire, les enregistrements sonores seront sauvegardés quotidiennement dans une clé USB, qui sera rangée dans un classeur verrouillé à l'Université Carlton.

Seuls le chercheur et le superviseur auront accès aux données de recherche et au fichier de codage permettant d'établir un lien entre vos renseignements personnels et les données de recherche. Aucun élément d'identification personnelle ne sera inclus dans les publications. Une fois l'étude terminée, le fichier de codage, les enregistrements sonores des entretiens et toutes les données de recherche seront gardés pendant cinq ans; ils pourraient être utilisés dans une future recherche sur le même sujet. Après cinq ans, toutes les données de recherche seront détruites d'une manière sécuritaire. Les copies papier des données de recherche (y compris le contenu des clés USB) seront rangées dans un classeur verrouillé à l'Université Carlton.

Vous n'êtes pas obligé(e) de répondre aux questions et vous pouvez vous retirer de l'étude à n'importe quel moment. En cas de retrait, vos renseignements personnels et les données de recherche recueillies seront détruits.

Si vous souhaitez obtenir un exemplaire de la publication de l'étude, veuillez communiquer avec le chercheur afin de recevoir une copie électronique.

L'étude a été examinée et autorisée par le Carleton University Research Ethics Board-B (Protocole $n^{\circ} 104849$ ). Si vous avez des questions ou des inquiétudes concernant votre participation à ce projet de recherche, veuillez communiquer avec :

Personnes-ressources du CUREB

Shelley Brown, présidente (CUREB-B)

Andy Adler, vice-président

Conseil d'éthique de la recherche de l'Université Carleton

Université Carleton

511 Tory

1125, promenade Colonel By

Ottawa ON K1S 5B6

+1 613-520-2600, poste 4085

ethics@carleton.ca 
Coordonnées du chercheur

Jed Looker

École de design industriel

Université Carleton

ed.looker@carleton.ca
Coordonnées du superviseur

Thomas Garvey

École de design industriel

Université Carleton

$+1613-520-2600$, poste 5674

thomas.garvey@carleton.ca

Acceptez-vous de participer à l'étude?

$\square$ Oui $\square$ Non

Acceptez-vous que l'entretien soit enregistré en audio? $\square$ Oui $\square$ Non

Signature du participant ou

Date

de la participante

Signature du chercheur

Date

Page 3 sur 3 
Appendix E Interview Questions

CUREB-B Clearance $\pi 104849$

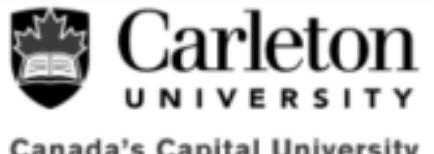

Interview Questions

\section{A. Sustainable Development Goals}

The first part of this study is focused specifically on the United Nations Sustainable Development Goals (SDGs) in relation to design schools.

1) Prior to this study, to what degree were you aware of the SDGs?

- No knowledge
- Aware
- Good comprehension

2) Do you feel the SDGs are an effective initiative for developing global awareness and action towards sustainable development concepts?

- Very ineffective

Ineffective

- Somewhat effective

- Effective

Very Effective

- Uncertain at this time

Why do you feel this way?

This document is for preview purposes only. 
3) Does your institution make reference to the SDGs in their strategic direction or plan?
- No
- Yes
- Uncertain at this time

Does your institution have other strategies, initiatives, commitments, institutes or centers that are focused on the SDGs?

4) To what extent are the SDGs included in your design school curricula?
- Never included
- Rarely included
- Occasionally included
- Frequently included
- Always included

Please provide examples of how the SDGs are included in your curricula (e.g. courses, lectures, activities, workshops, industry speakers, conferences, etc.).

5) Who at your institution would be typically responsible for introducing initiatives such as the SDGs into your design school curricula? Please check all that apply.
- President and VPs
- Deans and Chairs
Coordinators and Directors
- Professors, Lecturers and Instructors
- Student Leaders
- Other:

This document is for preview purposes only. 
6) As a coordinator at your institution, what would be the biggest challenge or obstacle you have faced-or might face-in introducing the SDGs to your design school curricula?

7) Do you feel the SDGs provide an effective framework for teaching sustainable development concepts to design school students?
- Very ineffective
Ineffective
Somewhat effective
Effective
Very Effective
- Uncertain at this time

Why do you feel this way?

8) In your experience, how often do the SDGs emerge in professional industrial/graphic design dialog, such as industry news, literature, websites, events and conferences?
- Never
- Rarely
- Occasionally
- Frequently
- Always

This document is for preview purposes only. 
9) How effective have professional design associations* been at raising awareness and engaging design school educators and students with the SDGs?

- Very ineffective

Ineffective

- Somewhat effective

- Effective

Very Effective

Can you elaborate on your answer?

Which of these design associations apply to your school?

10) What might these design associations do, or continue to do, to raise awareness and engage design school educators and students with the SDGs?

\footnotetext{
*Intemational Council of Societies of Industrial Design (ICSID); International Council of Design (ico-D); Association of Conodian industrial Designers (ACID); Associotion des designers industriels du Québec (ADIO); Association of Chartered Industrial Designers of Ontario (ACIDO); British Columbia Industrial Design Associotion (BCID); Graphic Designers of Conoda (GDC); Associotion of Registered Graphic Designers ( $R G D$ ); Societé des designers graphiques đu Québec ( $50 \mathrm{G} 0)$.
}

This document is for preview purposes only. 


\section{B. Sustainable Development Concepts}

The second part of this study is to gain an understanding of general social, economic and environmental sustainable development concepts as they relate to design schools. These concepts would be similar to, but are not specifically the SDGs (the SDGs are a UN initiative to categorize known sustainability concepts). For example, recycling is a general sustainable development concept, as is sourcing local produce, using environmentally friendly materials, or pay equity. They are the known concepts the SDGs are based on.

11) In your experience, how often do sustainable development concepts emerge in professional industrial/graphic design dialog such as industry news, literature, websites, events and conferences?
Never
Rarely
Occasionally
Frequently
Always

From your perspective, why do you think this is?

12) How often would you say professional industrial/graphic designers apply sustainable development concepts to the industry projects they are working on?
- Never
- Rarely
- Occasionally
- Frequently
- Always

Can you provide some examples of how professional designers apply sustainable development concepts to their projects?

This document is for preview purposes only. 
13) Has your institution included sustainable development concepts as part of their strategic direction or plan?
$\circ$ Yes
- No
- Uncertain at this time

Does your institution have other strategies, initiatives, commitments, institutes or centers that are focused on sustainable development concepts?

14) To what extent are sustainable development concepts included in your design school curricula?
- Never included
- Rarely included
- Occasionally included
- Frequently included
- Always included

Please provide examples of how these concepts are included in your curricula (e.g. courses, lectures, activities, workshops, industry speakers, conferences, etc.).

This document is for preview purposes only. 
15) What has been the reaction of your students to studying sustainable development concepts?

- Negative

Mostly negative

Indifferent

- Mostly positive

- Positive

- Uncertain at this time

Do you have any stories of your students reacting to sustainable development concepts?

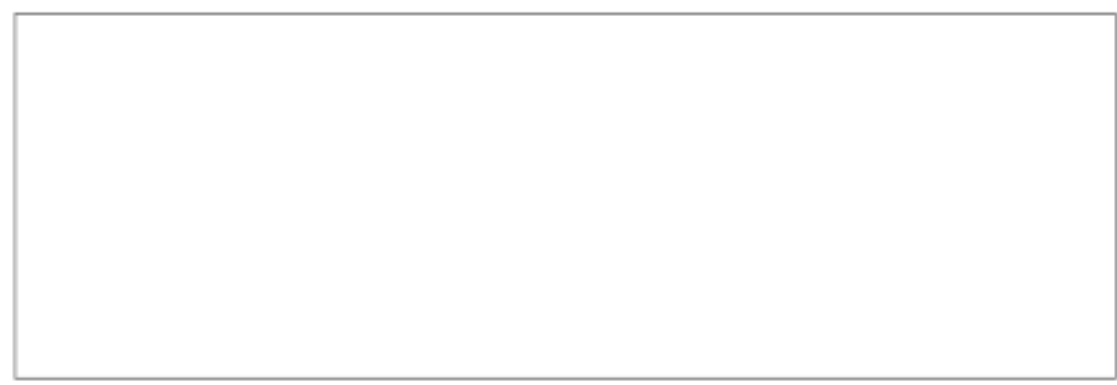

C. Post-Interview

We may following-up with some participants to get their feedback on the results of this survey. Would you be interested in participating?

- No

$\circ$ Yes

- Ask me again later

This document is for preview purposes only. 
Canada's Capital University

\section{Questions de l'entretien}

\section{A. Objectifs de développement durbale}

La première partie de l'étude est axée sur la prise en compte des Objectifs de développement durable $(O D D)$ des Nations Unies dans les écoles de design.

1) Connaissiez-vous l'existence des ODD avant la présente étude?

- Aucune connaissance

- Informé(e)

- Bonne compréhension

2) Pensez-vous que les ODD sont une initiative efficace pour sensibiliser la population mondiale aux concepts du développement durable et susciter des mesures?
- Très inefficace
Inefficace
Un quelque peu efficace
- Efficace
- Très efficace
- Incertain(e) pour l'instant
Pourquoi êtes-vous de cet avis?

Le présent document est destiné à des fins d'aperçu seulement. 
3) Est-ce que votre institution fait référence aux ODD dans son orientation ou plan stratégique?
$\circ$ Non
$\circ$ Oui
- Incertain(e) pour l'instant

Est-ce que votre institution possède d'autres stratégies, initiatives, engagements, instituts ou centres qui sont consacrés aux ODD?

4) Est-ce que les ODD sont inclus dans les programmes de votre école de design?
- Jamais inclus
- Rarement inclus
- Inclus à l'occasion
- Fréquemment inclus
- Toujours inclus

Veuillez donner des exemples de la façon dont les ODD sont inclus dans vos programmes ( $p$. ex., cours, cours magistraux, activités, ateliers, représentants de l'industrie ou conférences).

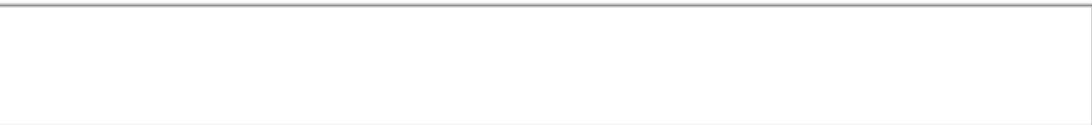

5) Dans votre institution, quelle personne est généralement chargée d'inclure les initiatives comme les ODD dans les programmes de votre école de design? Veuillez cocher toutes les réponses pertinentes.

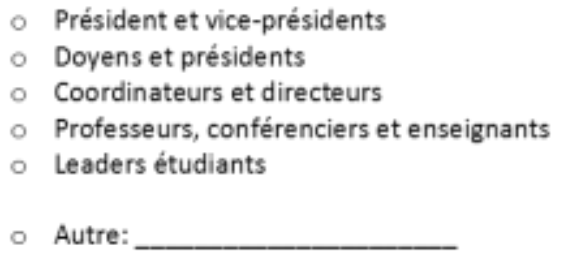

Le présent document est destiné à des fins d'aperçu seulement. 
6) En tant que coordinateur ou coordinatrice, quel est le plus grand défi ou obstacle auquel vous avez été - ou pourriez être - confronté(e) pour inclure les ODD dans les programmes de l'école de design de votre institution?

7) Pensez-vous que les ODD fournissent un cadre efficace pour enseigner les concepts du développement durable aux étudiants de l'école de design?
- Très inefficace
- Inefficace
- Un quelque peu efficace
- Efficace
- Très efficace
- Incertain(e) pour l'instant
Pourquoi êtes-vous de cet avis?

8) Selon votre expérience, à quelle fréquence les ODD sont-ils abordés dans le milieu professionnel de l'industrie ou du dessin industriel, par exemple dans les bulletins industriels, les publications, les sites Web, les activités et les conférences?
- Jamais
- Rarement
- Occasionnellement
- Fréquemment
- Toujours

Le présent document est destiné à des fins d'aperçu seulement. 
9) Est-ce que les associations professionnelles de design* sont efficaces pour sensibiliser les enseignants et étudiants des écoles de design aux ODD et les inciter à les adopter?

- Très inefficaces

Inefficaces

Un quelque peu efficaces

- Efficaces

Très efficacies

Pourriez-vous préciser votre réponse?

Laquelle de ces associations de design collabore avec votre école?

10) Qu'est-ce que ces associations de design pourraient faire ou continuer de faire pour sensibiliser davantage les enseignants et étudiants des écoles de design aux ODD et les inciter à les adopter?

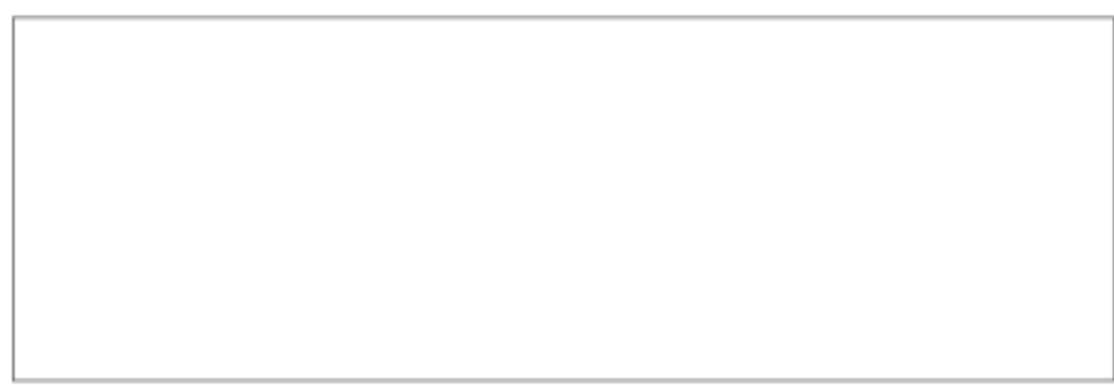

"Conseil international des saciétés de design industriel (CISDI); International Councif of Design (ico-D); Association des designers industriels du Canoda (ADIC); Association des designers industriels du Québec (ADIQ); Association of Chartered Industrial Designers of Ontario (ACIDO); British Columbia industrial Design Association (BCD); Grophic Designers of Canoda (GDC); Associotion des grophistes agréés (AGA); Sociéte des designers graphiques du Québec (SDGQ).

Le présent document est destiné à des fins d'aperçu seulement. 


\section{B. Concepts du développement durable}

La deuxième partie de l'étude a pour objectif d'évaluer la prise en compte des concepts environnementaux, économiques et sociaux généraux du développement durable dans les écoles de design. Ces concepts sont semblables aux ODD mais ce ne sont pas les $O D D$ (les $O D D$ sont une initiative des Nations Unies pour catégoriser des concepts de durabilité connus). Par exemple, le recyclage est un concept général du développement durable, à l'instar de la recherche de produits locaux, de l'utilisation de matériaux écologiques et l'équité salariale. II s'agit de concepts connus sur lesquels sont basés les $O D D$.

11) Selon votre expérience, à quelle fréquence les concepts du développement durable sontils abordés dans le milieu professionnel de l'industrie ou du dessin industriel, par exemple dans les bulletins industriels, les publications, les sites Web, les activités et les conférences?
Jamais
Rarement
Occasionnellement
Fréquemment
Toujours

À votre avis, pourquoi cette situation existe-elle?

12) A votre avis, est-ce que les designers industriels ou graphiques professionnels appliquent souvent les concepts du développement durable dans leurs projets industriels?
Jamais
Rarement
Occasionnellement
Fréquemment
Toujours

Pouvez-vous donner quelques exemples de la façon dont les designers professionnels appliquent les concepts du développement durable dans leurs projets?

Le présent document est destiné à des fins d'aperçu seulement. 
13) Est-ce que votre institution a intègré les concepts du développement durable dans son orientation ou plan stratégique?
$\circ$ Non
- Oui
- Incertain(e) pour l'instant

Est-ce que votre institution possède d'autres stratégies, initiatives, engagements, instituts ou centres qui sont consacrés aux concepts du développement durable?

14) Est-ce que les concepts du développement durable sont inclus dans les programmes de votre école de design?
- Jamais inclus
- Rarement inclus
- Inclus à l'occasion
- Fréquemment inclus
- Toujours inclus

Veuillez donner des exemples de la façon dont les concepts du développement durable sont inclus dans vos programmes (p. ex., cours, cours magistraux, activités, ateliers, représentants de l'industrie ou conférences).

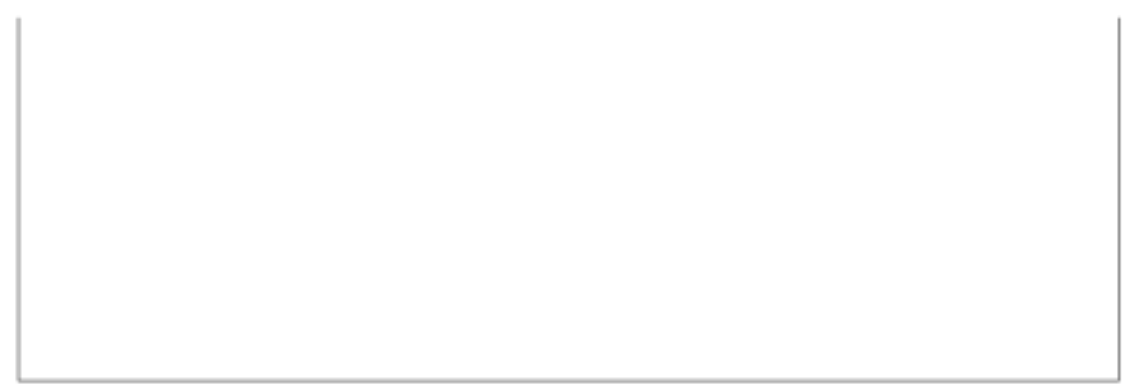

Le présent document est destiné à des fins d'aperçu seulement. 
15) Quelle a été la réaction de vos étudiants concernant l'étude des concepts du développement durable?
- Négative
- Surtout négative
- Indifférence
- Surtout positive
- Positive
- Incertain(e) pour l'instant

Avez-vous des exemples de réactions d'étudiants concernant les concepts du développement durable?

C. Étape suivant l'entretien

Nous souhaitons assurer un suivi auprès de quelques participants afin d'obtenir leur avis sur les résultats de l'étude. Souhaitez-vous figurer parmi ces participants?
Non
- Oui
- Veuillez me solliciter de nouveau plus tard

\footnotetext{
Le présent document est destiné à des fins d'aperçu seulement.
} 